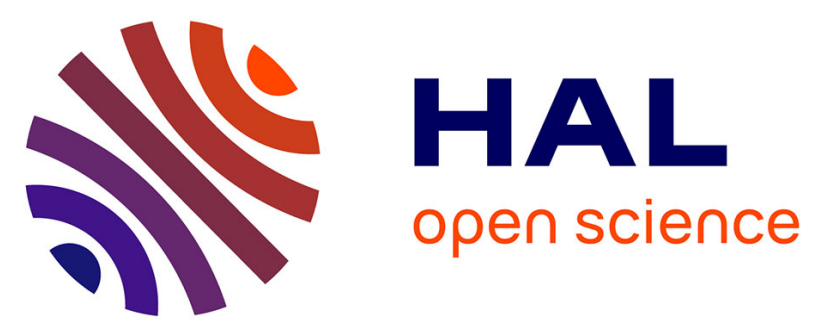

\title{
Multivalent Presentations of Glycomimetic Inhibitor of the Adhesion of Fungal Pathogen Candida albicans to Human Buccal Epithelial Cells
}

\author{
Harlei Martin, David Goyard, Anatte Margalit, Kyle Doherty, Olivier \\ Renaudet, Kevin Kavanagh, Trinidad Velasco-Torrijos
}

\section{To cite this version:}

Harlei Martin, David Goyard, Anatte Margalit, Kyle Doherty, Olivier Renaudet, et al.. Multivalent Presentations of Glycomimetic Inhibitor of the Adhesion of Fungal Pathogen Candida albicans to Human Buccal Epithelial Cells. Bioconjugate Chemistry, 2021, 32, pp.971 - 982. 10.1021/acs.bioconjchem.1c00115 . hal-03282485

\section{HAL Id: hal-03282485 \\ https://hal.science/hal-03282485}

Submitted on 9 Jul 2021

HAL is a multi-disciplinary open access archive for the deposit and dissemination of scientific research documents, whether they are published or not. The documents may come from teaching and research institutions in France or abroad, or from public or private research centers.
L'archive ouverte pluridisciplinaire HAL, est destinée au dépôt et à la diffusion de documents scientifiques de niveau recherche, publiés ou non, émanant des établissements d'enseignement et de recherche français ou étrangers, des laboratoires publics ou privés. 


\title{
Multivalent Presentations of Glycomimetic Inhibitor of the Adhesion of Fungal Pathogen Candida albicans to Human Buccal Epithelial Cells
}

\author{
Harlei Martin, David Goyard, Anatte Margalit, Kyle Doherty, Olivier Renaudet,* Kevin Kavanagh,* \\ and Trinidad Velasco-Torrijos*
}

Cite This: Bioconjugate Chem. 2021, 32, 971-982

Read Online

ACCESS | Lلll Metrics \& More | 回 Article Recommendations | sl Supporting Information

ABSTRACT: Candida albicans causes some of the most prevalent hospital-acquired fungal infections, particularly threatening for immunocompromised patients. C. albicans strongly adheres to the surface of epithelial cells so that subsequent colonization and biofilm formation can take place. Divalent galactoside glycomimetic 1 was found to be a potent inhibitor of the adhesion of $C$. albicans to buccal epithelial cells. In this work, we explore the effect of multivalent presentations of glycomimetic $\mathbf{1}$ on its ability to inhibit yeast adhesion and biofilm formation. Tetra-, hexa-, and hexadecavalent displays of compound 1 were built on RAFT cyclopeptide- and polylysine-based scaffolds with a highly efficient and modular synthesis. Biological evaluation revealed that the scaffold choice significantly influences the activity of the lower valency conjugates, with compound 16 , constructed on a tetravalent polylysine scaffold, found to inhibit the adhesion of $C$. albicans to human buccal epithelial cells more effectively than the glycomimetic 1; however, the latter performed better in the biofilm reduction assays. Interestingly, the higher valency glycoconjugates did not outperform the anti-adhesion activity of the original compound 1, and no significant effect of the core scaffold could be appreciated. SEM images of C. albicans cells treated with compounds 1, 14, and 16 revealed significant differences in the aggregation patterns of the yeast cells.

\section{INTRODUCTION}

The initiation of a multitude of human diseases is mediated by protein-carbohydrate recognition. ${ }^{1,2}$ For a microbe to infect its host, it first adheres to the host cell using adhesion proteins, many of which recognize carbohydrate epitopes displayed on the host cell surface. ${ }^{3}$ The development of small-molecule inhibitors of this adhesion process has been extensively studied. Glycoconjugates that mimic the glycans displayed on host cell surfaces are attractive candidates for the development of anti-adhesion compounds. ${ }^{4}$ Numerous ligands for microbial lectins found in pathogens such as Pseudomonas aeruginosa, Aspergillus fumigatus, and Escherichia coli have been reported. $^{5-10}$ Significantly, the crystal structures of these adhesins have been solved, which has facilitated structurebased ligand design. ${ }^{11-13}$ However, carbohydrates interact with their protein receptors with low affinity, with dissociation constants typically in the millimolar to micromolar range. ${ }^{14}$ Consequently, a major focus of glycoscience research involves the development of strategies for increasing the lectin-ligand binding affinities to levels required for therapeutic use. ${ }^{15}$ This can be achieved through the glycomimetic approach or through utilizing the multivalent or cluster glycoside effect. ${ }^{5,16}$ Multivalent glycoconjugates with diverse valencies and spatial

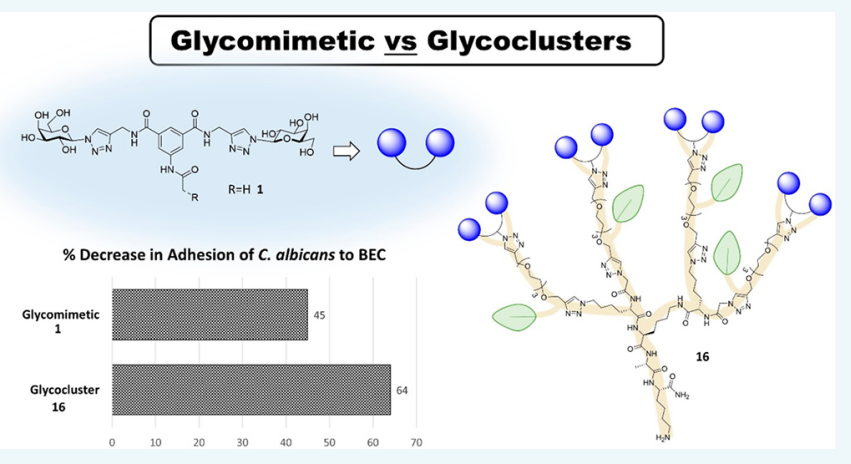

arrangements of recognition epitopes have been developed to increase the affinity of carbohydrates for their target proteins. ${ }^{17}$ These multivalent constructs can have well-defined molecular structures and display a specific number of carbohydrate ligands when they are built around scaffolds such as calixarenes, ${ }^{18}$ dendrimers, ${ }^{19}$ cyclodextrins, ${ }^{20}$ and fullerenes; ${ }^{21}$ higher valencies with more variable degrees of substitution are achieved when using polymers, ${ }^{22}$ nanoparticles, ${ }^{23}$ and quantum dots. $^{24}$ Even with the extensive research carried out in this field, it still remains extremely challenging to predict optimal multivalent presentations that result in enhanced binding affinities for a specific target.

Lysine-containing cyclodecapeptides called "regioselectively addressable functionalized templates" (RAFT) were first described as stable scaffolds for the de novo design of proteins

Received: March 6, 2021

Revised: April 8, 2021

Published: April 22, 2021 

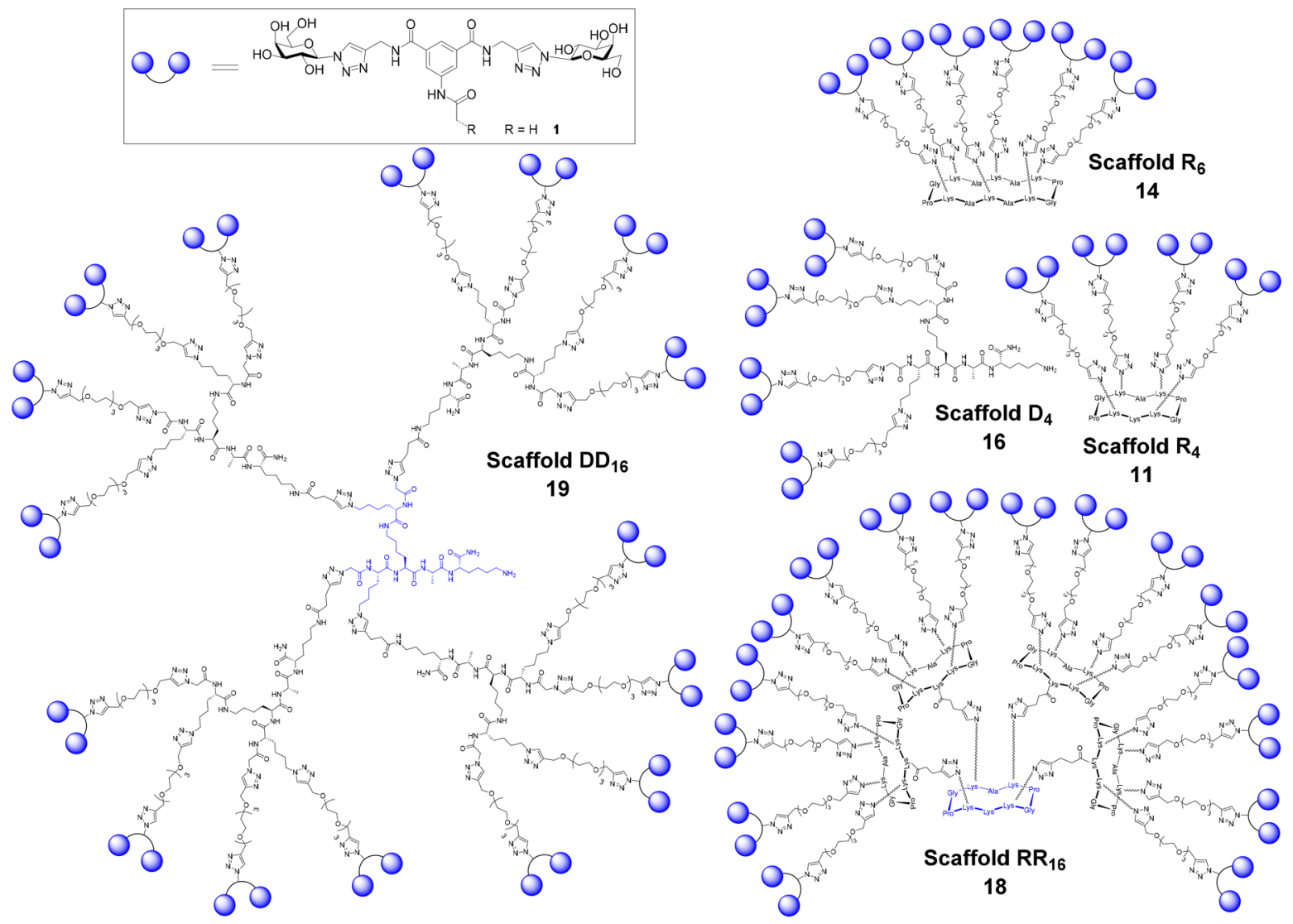

Figure 1. Structure of lead compound 1 and multivalent displays on tetra-, hexa-, and hexadecavalent RAFT cyclopeptides $\left(R_{4} 11, R_{6} 14, R_{16} 18\right)$ and dendrimeric polylysine $\left(\mathrm{D}_{4} 16, \mathrm{DD}_{16} 19\right)$ scaffolds.

or as peptidomimics. ${ }^{25}$ These scaffolds have a defined and constrained structure, and the presence of the lysine residue in the amino acid sequence has allowed for further functionalization and display of carbohydrates in a multivalent manner. In order to improve the recognition properties of the cyclopeptide-based glycoclusters toward lectins, newer generations with higher valency and varying levels of rigidity have been developed by Renaudet and co-workers. A modular chemoselective strategy was used to introduce either a flexible polylysine framework or a constrained cyclopeptide onto the RAFT core, providing two different hyperbranched skeletons in a controlled manner. Biologically relevant carbohydrates were then conjugated to obtain a new series of glycodendrimer-like structures. ${ }^{26}$ These structures have been used to generate highly potent ligands for interactions with different lectins. $^{27}$ For example, multivalent cyclopeptide scaffolds presenting $N$-acetyl glucosamine (GlcNAc), $N$-acetyl galactosamine (GalNAc), and, more recently, mannose (Man) moieties have been shown to bind the lectins wheat germ agglutinin, ${ }^{28}$ soybean agglutinin, ${ }^{29}$ and DC-SIGN, ${ }^{30}$ respectively, at micro- and nanomolar concentrations. Glycoclusters based on RAFT and polylysine scaffolds displaying several copies of $\alpha$-fucose (Fuc) and $\beta$-galactose (Gal) have also been found to have high affinity for LecA and LecB, important adhesins from Pseudomonas aeruginosa. ${ }^{31,32}$ A glycodendron displaying $24 \alpha$-mannosides was found to bind BC2L-A, a lectin from respiratory pathogen Burkholderia cenocepacia, at nanomolar concentration. ${ }^{33}$ Interestingly, glycomimetics with affinity toward fucose-binding receptors from emerging pathogens Aspergillus fumigatus and Burkholderia ambifaria were grafted onto hexavalent RAFT scaffolds and showed dissociation constants in the low nanomolar range. ${ }^{34}$

Candida albicans is an opportunistic pathogenic yeast and is the most prevalent cause of fungal infections worldwide, particularly in hospital-acquired infections. ${ }^{35-37}$ The yeast is capable of causing a wide range of superficial and systemic infections in the immunocompromised patient, and there is now also growing concern for the coinfection of fungal pathogens in Covid-19 patients. ${ }^{38-40}$ It is therefore extremely important that new treatments are developed for these fungal infections, some of which are now showing resistance to conventional antifungal therapies. ${ }^{41}$ Compound 1 (Figure 1) was previously reported by us as a successful inhibitor of $C$. albicans adhesion to human buccal epithelial cells (BECs). ${ }^{42,43}$ The presence of the two triazolyl galactosides in compound 1 was found to be critical for its activity, as glycoconjugates with carbohydrates other than galactose displayed on the same aromatic scaffold had reduced the anti-adhesion effect or provided no effect at all. Given the versatility of the RAFT cyclopeptide and dendrimeric polylysine scaffolds, herein we describe their use to prepare multivalent displays of the glycomimetic 1 (shown in Figure 1) and investigate their efficacy at inhibiting the adhesion of C. albicans to BECs. Lead compound 1 was modified with a suitable triethylene glycol linker to facilitate connection with these scaffolds using the highly efficient copper-catalyzed azide-alkyne cycloaddition (CuAAC) methodology. Since the structure of the target lectin in C. albicans is not known, ligand optimization requires the 
Scheme 1. Inset Shows the Structure of Lead Compound 1. Synthesis of Compound $9^{a}$

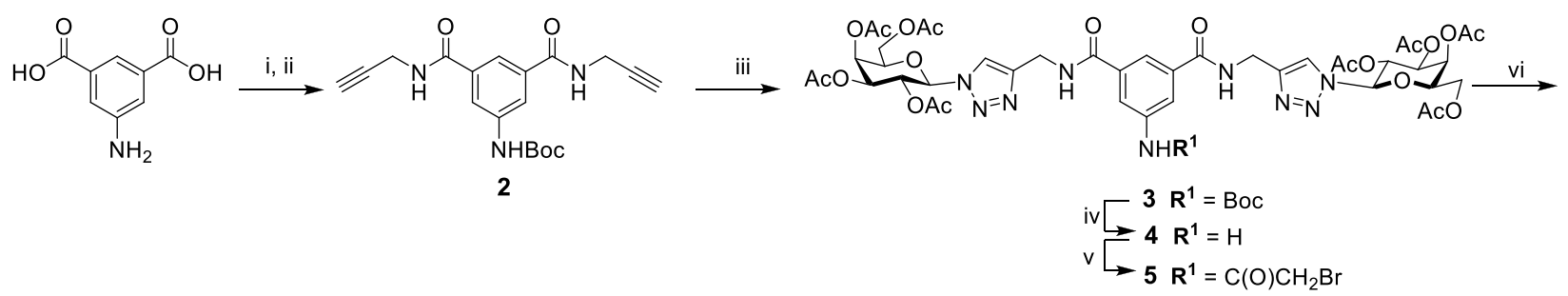

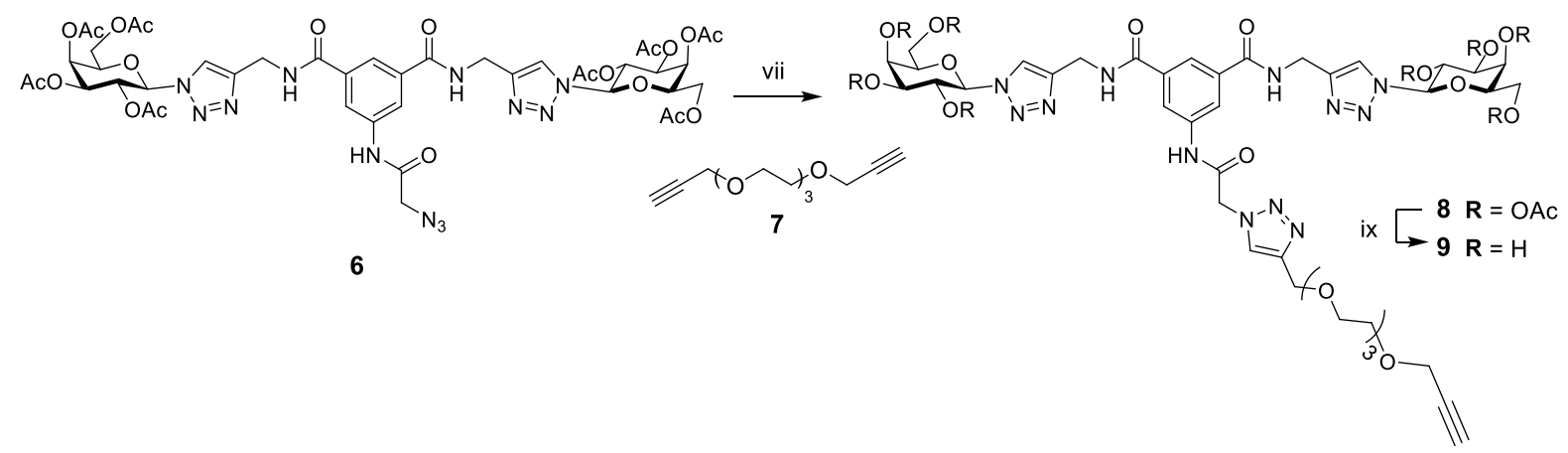

${ }^{a}$ Reagents and conditions: (i) Di-tert-butyl dicarbonate, $\mathrm{NaOH}, 1,4$-dioxane, $0{ }^{\circ} \mathrm{C}$ to rt, $3 \mathrm{~h}, 86 \%$; (ii) DMTMM, propargylamine, THF, $48 \mathrm{~h}, 95 \%$; (iii) 2,3,4,6-tetra-O-acetyl-1- $\beta$-azido-galactoside, $\mathrm{CuSO}_{4} \cdot 5 \mathrm{H}_{2} \mathrm{O} /$ sodium ascorbate ( $\mathrm{Na} \mathrm{Asc}$ ), $\mathrm{CH}_{3} \mathrm{COCH}_{3} / \mathrm{H}_{2} \mathrm{O}$, rt, $16 \mathrm{~h}, 71 \%$; (iv) TFA, DCM, $2 \mathrm{~h}$, rt, 99\%; (v) bromoacetyl bromide, $\mathrm{NEt}_{3}$, anhydrous DCM, $16 \mathrm{~h}, 83 \%$; (vi) $\mathrm{NaN}_{3}$, anhydrous $\mathrm{DMF}, \mathrm{N}_{2}, 80{ }^{\circ} \mathrm{C}, 16 \mathrm{~h}$, quant \%; (vii) $7, \mathrm{CuSO}{ }_{4}$. $5 \mathrm{H}_{2} \mathrm{O} / \mathrm{Na}$ Asc, $\mathrm{CH}_{3} \mathrm{CN} / \mathrm{H}_{2} \mathrm{O}, \mathrm{MW}, 100{ }^{\circ} \mathrm{C}, 10 \mathrm{~min}, 45 \%$; (ix) $\mathrm{MeOH} \mathrm{NEt}_{3}, \mathrm{H}_{2} \mathrm{O}, 45^{\circ} \mathrm{C}, 6 \mathrm{~h}, 90 \%$.

screening of a diverse range of multivalent presentations to identify the optimum structural parameters (i.e., valency, flexibility, and three-dimensional orientation) to achieve increased anti-adhesion activities.

\section{RESULTS AND DISCUSSION}

Chemical Synthesis. The scaffolds chosen for this study included RAFT cyclopeptides containing four $\left(\mathrm{R}_{4}, 10\right)$ or six $\left(R_{6}, 13\right)$ lysines oriented out of the upper domain of the scaffold, and a flexible lysine-based dendron $\left(\mathrm{D}_{4}, 15\right)$, all previously reported by Renaudet and co-workers. ${ }^{32,33,44}$ All these scaffolds featured azide groups, which required the functionalization of lead compound $\mathbf{1}$ with an alkyne group in order to use CuAAC protocols. Lead compound $\mathbf{1}$ was therefore modified with a triethylene glycol linker with a terminal propargyl group as shown in Scheme 1. Based on our previously reported synthesis, ${ }^{42}$ 5-amino-isophthalic acid was $N$-Boc protected, followed by reaction with propargylamine and TBTU to give aromatic-centered diamide scaffold 2 . CuAAC chemistry was used to conjugate the acetylated galactose azides to the scaffold to give compound 3. N-Bocdeprotection with TFA yielded compound 4, which was reacted with bromoacetyl bromide to give $\mathbf{5}$ and subsequently converted to compound 6 by reaction with sodium azide. Separately, triethylene glycol was reacted with propargyl bromide to give dialkyne linker $7 .^{45}$ This was then reacted with the azide derivative 6 using CuAAC methodology. To promote reaction with only one alkynyl group, this reaction was carried out in dilute conditions and with a large excess of linker 7, giving the desired monoalkynyl compound 8 and unreacted linker 7 as the major outcomes of the reaction after column chromatography. Deacetylation of $\mathbf{8}$ under mild basic conditions gave key synthetic intermediate $\mathbf{9}$, as it presents an alkyne that will allow for conjugation to the peptidic scaffold functionalized with azido groups.
We next prepared three different glycoclusters with valencies of four and six. Azide-containing cyclopeptide scaffolds $\mathrm{R}_{4} \mathbf{1 0}$ and $R_{6} 13$ and lysine-based dendron $D_{4} 15$ were prepared using previously reported procedures. ${ }^{32,33,44}$ Coupling of these three scaffolds with compound 9 using the CuAAC protocol gave glycoclusters 11, 14, and 16, respectively. In order to prepare glycodendrimers with higher valencies, compounds 11 and 16 were further functionalized by reacting them with $N$ succinimidyl pentynoate under basic conditions to yield compounds 12 and 17, respectively (Scheme 2).

Compound 12 was then coupled to another azide-functionalized RAFT cyclopeptide 10 using the same CuAAC conditions to give glycocluster 18. This compound features 16 copies of the lead compound attached to rigid cyclopeptide cores, resulting in the display of 32 galactose residues. Similarly, compound $\mathbf{1 7}$ was then coupled to another azidefunctionalized polylysine scaffold $\mathbf{1 5}$ to give the glycodendrimer 19, which, like compound $\mathbf{1 8}$, has 16 copies of the lead compound. However, compound 19 provides a more flexible presentation of the 32 galactose moieties (Scheme 3). All the final compounds were purified by preparative HPLC and characterized by mass spectrometry.

Biological Evaluation. Adhesion assays to assess the ability of the multivalent compounds to inhibit C. albicans adhesion to human BECs were carried out with all glycoclusters and dendrimers, using the original lead compound $\mathbf{1}$ as a positive control (Figure 2). An exclusion assay was first performed where the yeast cells were pretreated with the glycoconjugates, prior to exposure to BECs. As seen in Figure 2, the tetravalent polylysine glycodendrimer 16 achieved better results than lead compound 1, inhibiting the yeast adhesion by $64 \%$. Interestingly, tetravalent glycocuster 11, based on a RAFT cyclopeptide scaffold, showed only $30 \%$ inhibition, approximately half of the activity of analogue 16, highlighting the critical role of the core scaffolds on the overall presentation of the recognition epitopes. Compound 14, based 
Scheme 2. Synthesis of Glycoclusters ${ }^{a}$

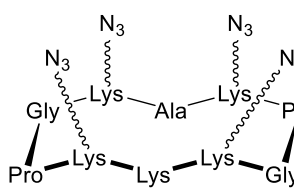

10

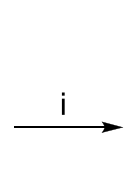

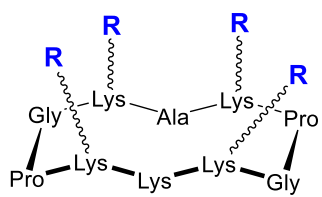

11

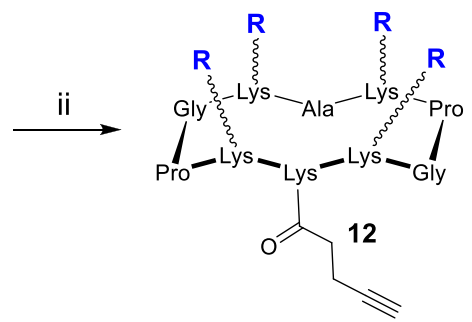

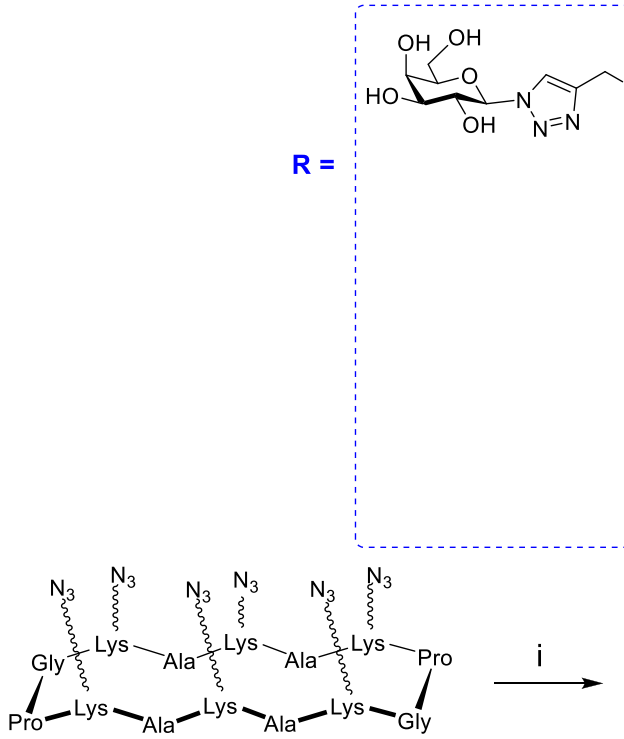

13

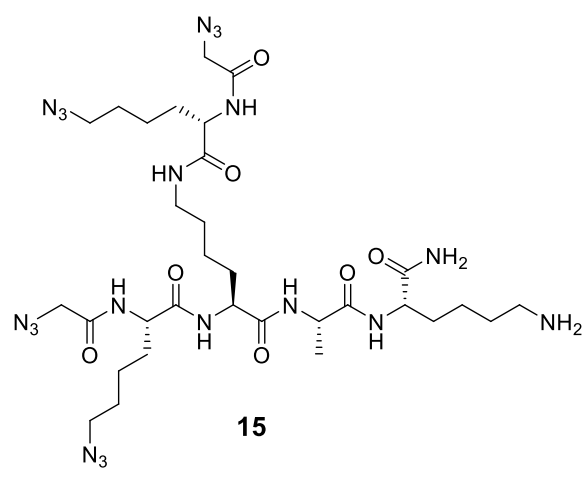

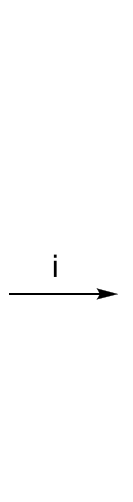

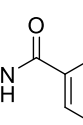<smiles>O=Cc1cccc(NC(=O)Cn2ccnn2)c1</smiles><smiles>CC(=O)NCc1cn(COC(O)C(O)C(O)C(O)CO)nn1</smiles><smiles>c1cn[nH]c1</smiles>

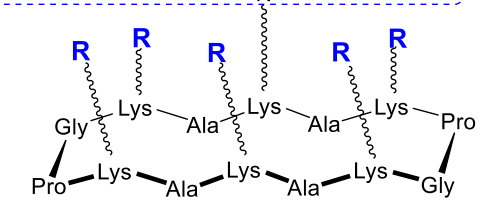

14

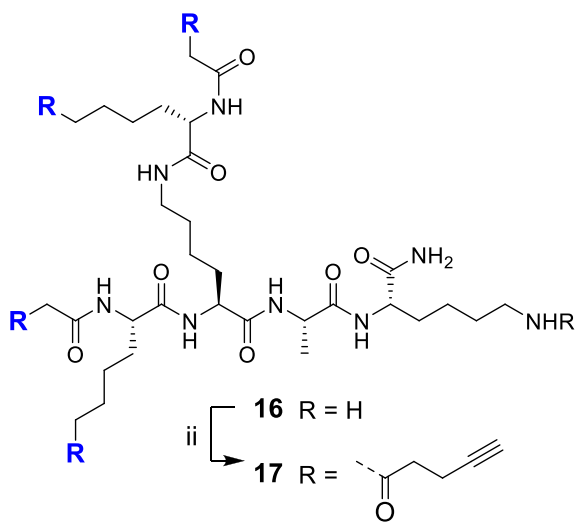

${ }^{a}$ Reagents and conditions: (i) 9, $\mathrm{CuSO}_{4} \cdot 5 \mathrm{H}_{2} \mathrm{O} / \mathrm{Na}$ Asc, THPTA, DMF/PBS buffer (pH 7.5), rt, $1 \mathrm{~h}, 34-78 \%$; (ii) $N$-succinimidyl pentynoate, DIPEA, DMF ( $\mathrm{pH}$ 9), rt, 1 h, 82-97\%. All amino acids have L-configuration.

on a RAFT hexavalent scaffold, had very comparable results to the original compound 1 ( $47 \%$ and $45 \%$, respectively). On the other hand, the higher valency glycoconjugates 18 and 19, displaying 16 copies of the lead compound 1 , performed very similarly, independently of the structure of the core scaffolds used: neither of them surpassed the inhibition activity of compound 1, with 33\% inhibition for RAFT-based 18 and 34\% inhibition for glycodendrimer 19.

The competition assays, where C. albicans yeast cells, BECs, and glycoclusters/dendrimers were coincubated, showed a similar trend to the previous assays (Figure 2): Again, compound 16 based on the tetravalent polylysine scaffold was the most effective inhibitor, with a $62 \%$ reduction of adhesion, outperforming lead compound 1 (48\%). Both tetra- and hexavalent glycoconjugates built on cyclic RAFT scaffolds (compounds 11 (33\%) and 14 (42\%), respectively) did not inhibit the adhesion as well as compound 1. The higher valencies displayed by both the hexadecavalent glycoconjugates $18(38 \%)$ and $19(40 \%)$ resulted once again in comparable inhibition of adhesion of C. albicans, irrespectively of the core scaffold architectures.

SEM Imaging. SEM was used to observe the morphology of C. albicans cells after $24 \mathrm{~h}$ exposure to the lead compound 1 and glycoclusters 14 and 16, the best performing of the multivalent glycoconjugates (Figure 3). In the control (not treated) samples, the transition of some of the yeast cells to hyphae and pseudohyphae can be observed, while these morphologies were not evident in the samples treated with the 


\section{Scheme 3. Synthesis of Glycodendrimers 18 and $19^{a}$}

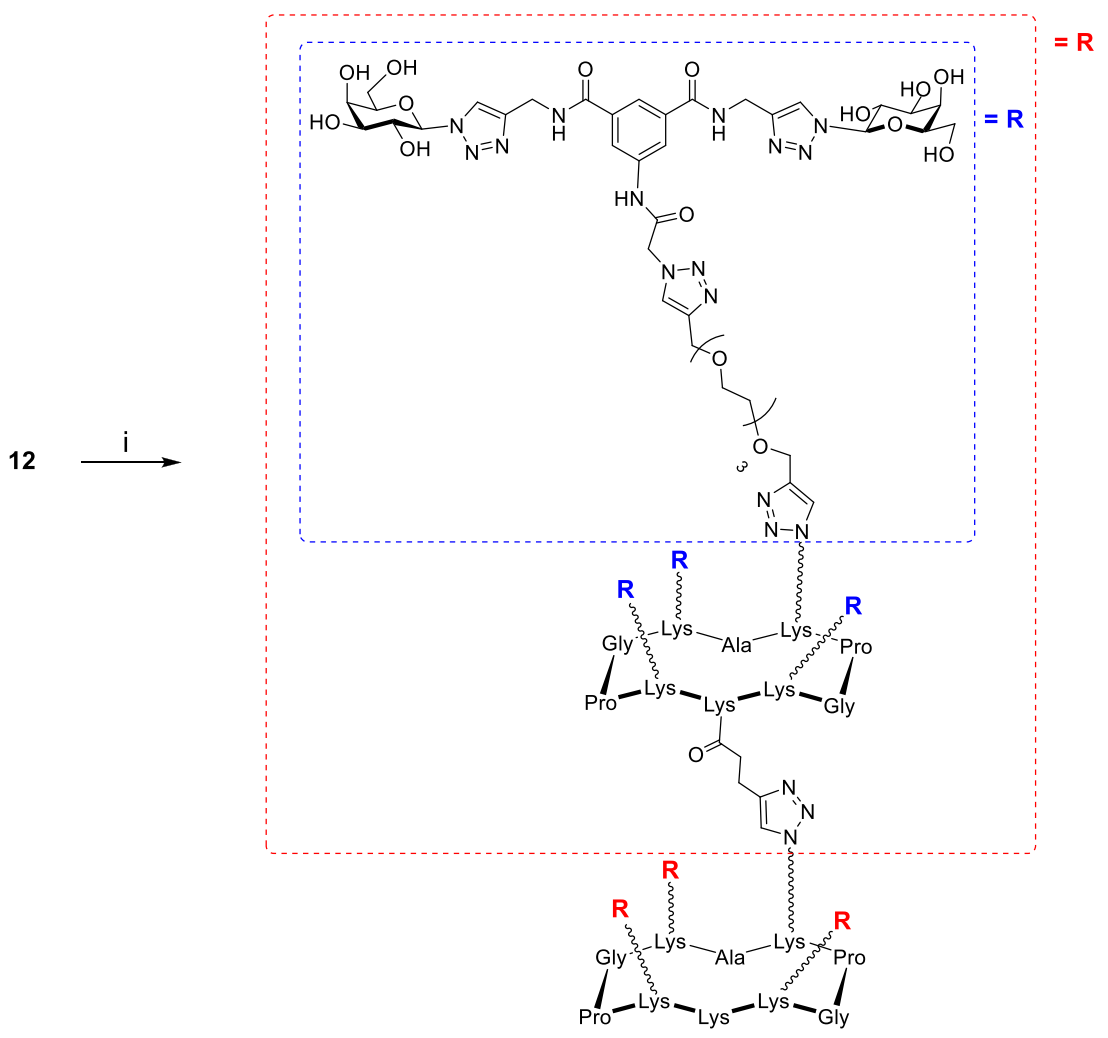

18

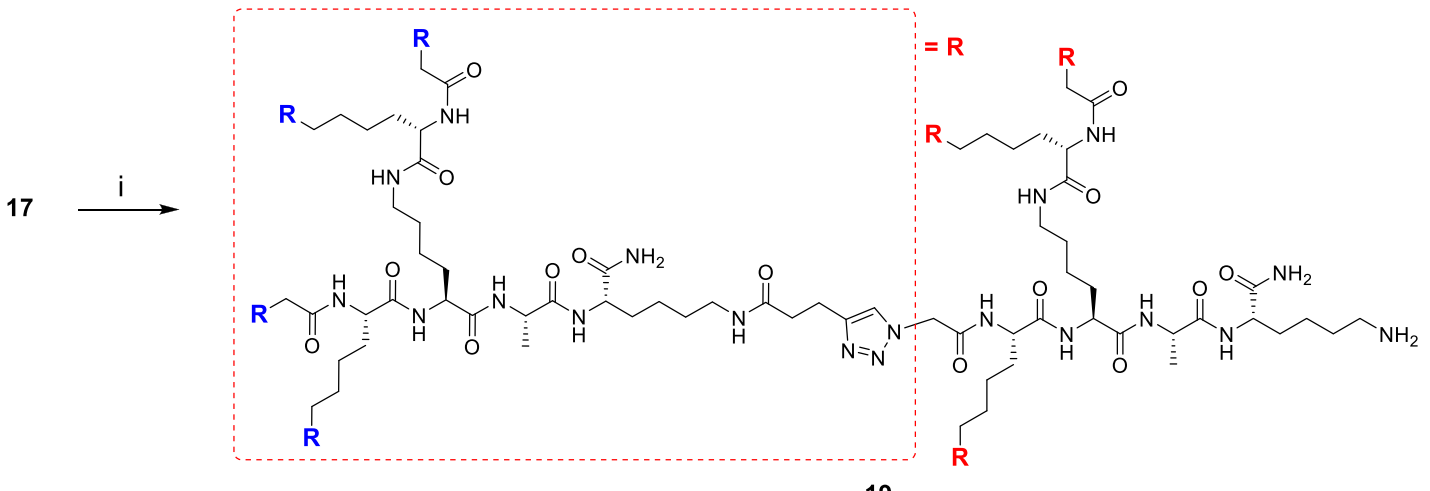

19

${ }^{a}$ Reagents and conditions: (i) $\mathrm{CuSO}_{4} \cdot 5 \mathrm{H}_{2} \mathrm{O} / \mathrm{Na}$ Asc, THPTA, DMF/PBS buffer (pH 7.5), rt, 1 h, 87-89\%.

glycoconjugates. Interestingly, while larger clumps of yeast cells were observed for the control sample, the cells treated with compound 1 appeared more dispersed. The yeast exposed to glycodendrimers 14 and 16 showed just a few cells aggregating tightly. These images suggest that, although both compound 1 and 16 display the same divalent galactoside glycomimetic epitope, the mechanisms by which they interact with structural components of the cell wall in C. albicans may be different. Yeast adhesion processes are critical in the development of biofilms. ${ }^{46}$ The ability of these compounds to interfere with adhesion processes may be advantageous to prevent morphogenesis and biofilm formation, which are major virulence factors in C. albicans infections. ${ }^{47}$

Biofilm Assays. Biofilm assays were then carried out using D-galactose, lead compound 1, and multivalent glycodendrimer 16. C. albicans has the ability to form biofilms, a major virulence characteristic of this pathogen. ${ }^{48}$ The extracellular matrix which forms during the maturation stage of biofilm development, encompasses a complex network of yeast, pseudohyphal, and hyphal cells, forming densely packed groups of cells adhered to a surface. These biofilms are inherently resistant to conventional antifungal drugs and the host immune system, causing a huge problem in clinical infections. ${ }^{49}$ Hence, the discovery of a treatment that can inhibit the initial adhesion process of the yeast and prevent the formation of biofilms is hugely desirable.

Before the biofilm assays, the compounds were tested for their fungicidal properties, showing no toxicity toward $C$. albicans (Figure S24). Under biofilm growing conditions, $C$. albicans cultures were treated with D-galactose as a positive control, ${ }^{50}$ lead compound 1 and glycodendrimer $\mathbf{1 6}$. As shown in Figure 4, D-galactose promoted the formation of the biofilm, while glycomimetic $\mathbf{1}$ decreased the formation of the biofilm by over $30 \%$, highlighting the potential antivirulence activity of 

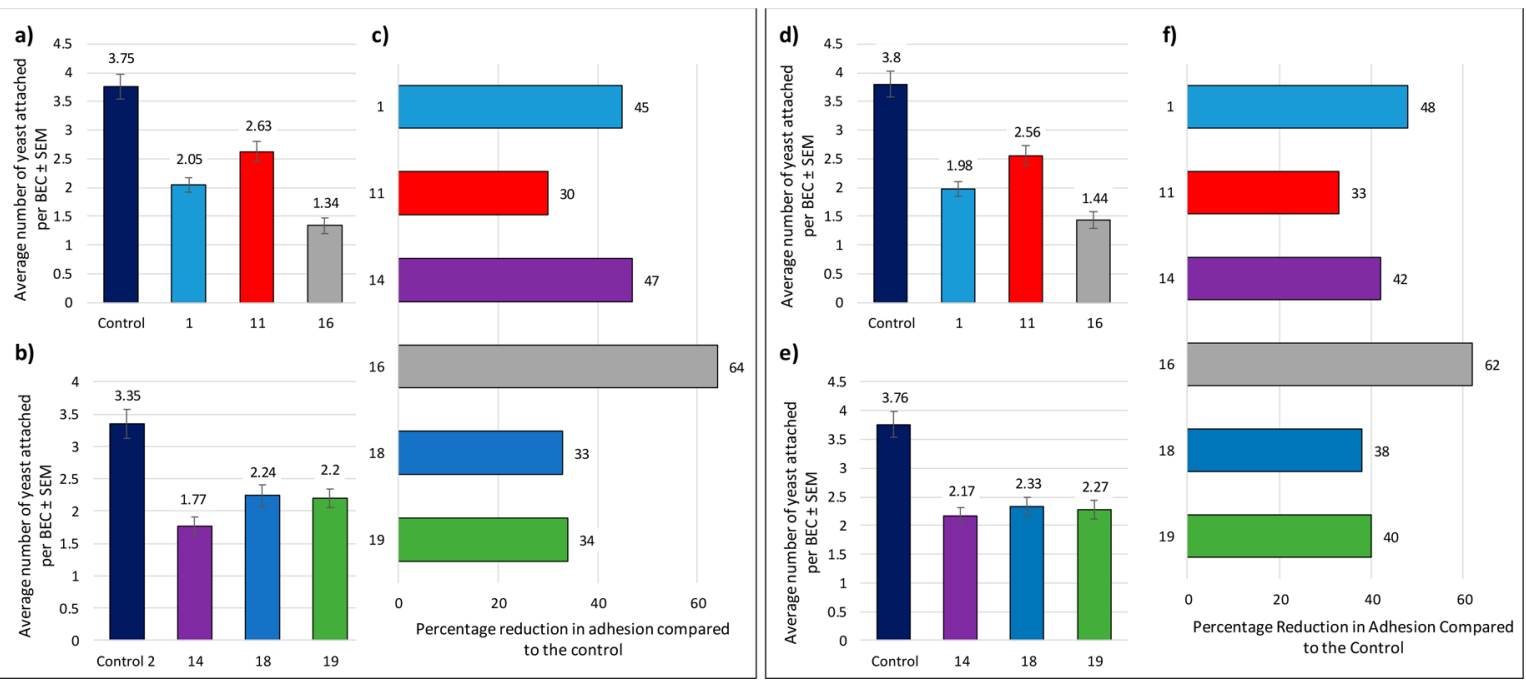

Figure 2. Left: Exclusion assays where C. albicans yeast cells were pretreated with the glycoconjugates before incubation with BECs: (a) and (b) show the average number of yeast cells attached per BEC; (c) shows the percentage reduction in adhesion compared to the control (Phosphate Buffer solution, PBS). Right: Competition assays where the C. albicans yeast cells, BECs, and glycoconjugates were coincubated: (a) and (b) show the average number of yeast cells attached per BEC; (c) shows the percentage reduction in adhesion compared to the control (PBS). All compounds were tested at $1 \mathrm{mg} / \mathrm{mL}$ (see also ESI-Table 1).

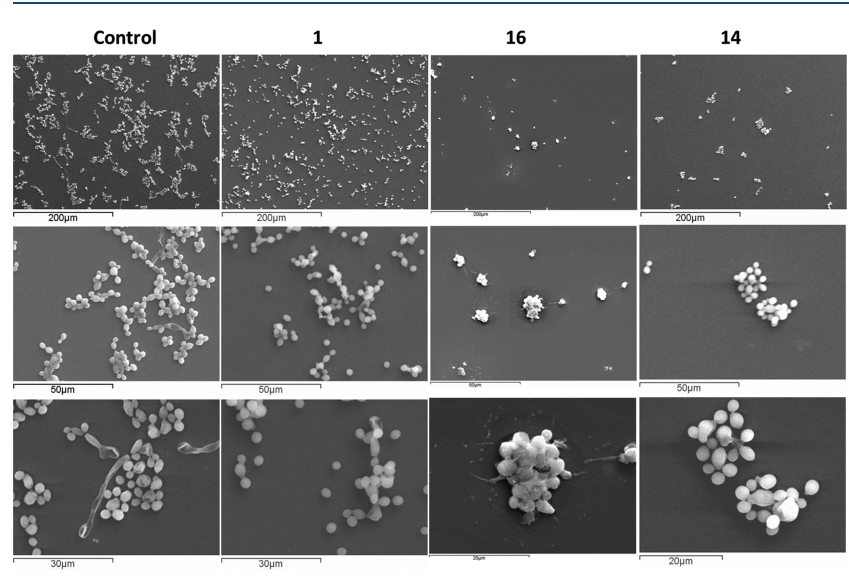

Figure 3. SEM images of C. albicans yeast cells at different magnifications after treatment with PBS, lead compound $\mathbf{1}$, tetravalent glycodendrimer 16, and hexavalent glycocluster 14.

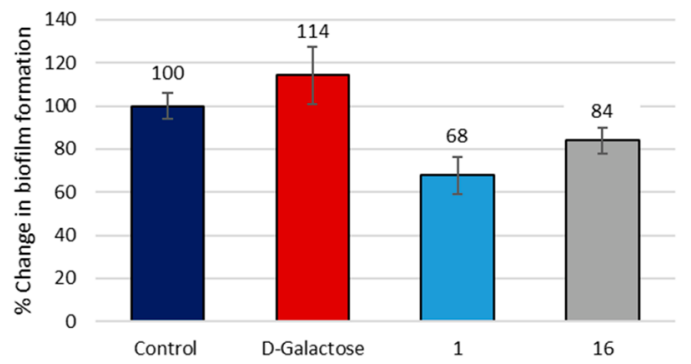

Figure 4. Biofilm inhibition showing the percentage change in the biofilm formation. Control: PBS. (Error: Standard deviation).

this compound. Surprisingly, even though compound 16 preformed best in the adhesion assays, it was slightly less effective than 1 at reducing biofilm formation (26\%).

In summary, five novel multivalent displays of anti-adhesion glycomimetic 1 were successfully synthesized. The core divalent galactosyl structure required for biological activity was functionalized with a triethylene glycol linker appended with a terminal alkyne group. Using CuAAC chemistry, this was connected to azide-containing scaffolds to form tetra-, hexa-, and hexadecavalent RAFT cyclopeptides $\left(\mathrm{R}_{4} 11, \mathrm{R}_{6} 14\right.$, $\left.R_{16} 18\right)$ and dendrimeric polylysine $\left(D_{4} 16, D_{16} 19\right)$ based multivalent displays of compound 1. Anti-adhesion assays on these compounds (Table 1) showed that the core peptidic

Table 1. Summary of Anti-Adhesion Activity of Lead Compound 1 Glycomimetic 1, the Lower Valency Glycoclusters 11, 14, and 16, and the Higher Valency Glycoclusters 18 and 19

\begin{tabular}{lccc} 
compound & $\begin{array}{c}\text { number of copies } \\
\text { of the } \\
\text { glycomimetic }\end{array}$ & $\begin{array}{c}\text { exclusion assay: \% } \\
\text { reduction in } \\
\text { adhesion }\end{array}$ & $\begin{array}{c}\text { competition assay: \% } \\
\text { reduction in } \\
\text { adhesion }\end{array}$ \\
$\mathbf{1}$ & 1 & 45 & 48 \\
$\mathbf{1 1}\left(\mathrm{R}_{4}\right)$ & 4 & 30 & 33 \\
$\mathbf{1 4}\left(\mathrm{R}_{6}\right)$ & 6 & 47 & 42 \\
$\mathbf{1 6}\left(\mathrm{D}_{4}\right)$ & 4 & 64 & 62 \\
$\mathbf{1 8}\left(\mathrm{RR}_{16}\right)$ & 16 & 33 & 38 \\
$\mathbf{1 9}\left(\mathrm{DD}_{16}\right)$ & 16 & 34 & 40 \\
\hline
\end{tabular}

scaffold strongly influences the presentation of the glycomimetic structure in the multivalent glycoclusters, and hence their ability to inhibit adhesion of C. albicans to human BECs: tetravalent glycodendrimer 16 outperformed the original compound 1, inhibiting over $60 \%$ of yeast adhesion to BECs. In contrast, tetravalent counterpart 11, built onto a RAFT cyclopeptide scaffold, showed only approximately half the activity (30\% reduction in adhesion), being a less effective inhibitor than monomer 1 (with $45 \%$ reduction). Interestingly, an increase in the number of copies of glycomimetic 1 did not result in an improvement of anti-adhesion activity, with hexavalent 14 and hexadecavalent compounds 18 and 19 performing comparably or slightly worse than original inhibitor 1 , regardless of the chemical structure of the core scaffolds. As discussed earlier, remarkable increases in affinity toward isolated bacterial and fungal lectins have been reported upon multivalent display of carbohydrate epitopes. However, it is 
possible that whole bacterial or fungal cells, with the inherent complexity of the cell wall, present a more challenging environment for large glycoclusters to be able to access optimal three-dimensional presentations. A glycomimetic approach, guided by structural knowledge of the target proteins, may promote more effective interactions. In fact, the SEM images of $C$. albicans yeast cells treated with glycoclusters 14 and 16 showed distinctly different yeast adhesion patterns when compared to original compound $\mathbf{1}$, even if these compounds were all effective inhibitors of yeast adhesion to BECs. Overall, this work highlights that increasing the number of glycomimetic epitopes presented by multivalent scaffolds does not necessarily result in an increase of biological activity. In particular, for the inhibitors of the adhesion of $C$. albicans discussed herein, lower valency dendrimeric presentations yielded the most promising results.

\section{EXPERIMENTAL PROCEDURES}

Synthesis. General Methods. All reagents for synthesis were bought commercially and used without further purification. Reactions were monitored with thin layer chromatography (TLC) on Merck Silica Gel $\mathrm{F}_{254}$ plates. Detection was effected by UV $(\lambda=254 \mathrm{~nm})$ or charring in a mixture of $5 \%$ sulfuric acid-ethanol. NMR spectra were recorded using Bruker Ascend 500 and Avance III spectrometers at $293 \mathrm{~K}$. All chemical shifts were referenced relative to the relevant deuterated solvent residual peaks. Assignments of the NMR spectra were deduced using ${ }^{1} \mathrm{H}$ NMR and ${ }^{13} \mathrm{C}$ NMR, along with $2 \mathrm{D}$ experiments (COSY, HSQC, and HMBC). Chemical shifts are reported in ppm. Flash chromatography was performed with Merck Silica Gel 60. Microwave $(\mu \mathrm{W})$ reactions were carried out using a CEM Discover Microwave Synthesizer. Optical rotations were obtained from an AA-100 polarimeter and $[\alpha]_{\mathrm{D}}$ values are given in $10^{-1} \mathrm{~cm}^{2} \cdot \mathrm{g}^{-1}$. High resolution mass spectrometry (HRMS) was performed on an Agilent-LC 1200 Series coupled to a 6210 Agilent Time-Of-Flight (TOF) and a Waters Xevo G2-S QToF mass spectrometers equipped with an electrospray source in both positive and negative (ESI \pm ) modes. SEM images were taken on a HITACHI S-3200N Scanning Electron Microscope. FT-IR spectra were recorded on a PerkinElmer Spectrum 100 spectrophotometer, via ATR as a solid on a zinc selenide crystal or as a film on $\mathrm{NaCl}$ plates in the region $4000-400 \mathrm{~cm}^{-1}$. Spectroscopic data for all compounds are provided in the Supporting Information.

$N, N^{\prime}$-Di(2,3,4,6-tetra-O-acetyl- $\beta$-D-galactopyranosyl1,2,3-triazol-4-ylmethylamide)- $N^{\prime \prime}$-(2-bromoacetamido)-5aminobenzene-1,3-dicarboxamide (5). Compound $4^{42}$ $(1.128 \mathrm{~g}, 1.13 \mathrm{mmol})$ was dissolved in dry DCM $(20 \mathrm{~mL})$. $\mathrm{NEt}_{3}(0.19 \mathrm{~mL}, 1.35 \mathrm{mmol})$ was added to this solution. Bromoacetyl bromide $(0.12 \mathrm{~mL}, 1.35 \mathrm{mmol})$ was dissolved in dry DCM $(5 \mathrm{~mL})$ in a separate round-bottom flask. The first solution was added to the second dropwise via a cannula, and the resulting reaction mixture was allowed to stir for $16 \mathrm{~h}$. The reaction mixture was washed with water $(20 \mathrm{~mL}), \mathrm{HCl}(1 \mathrm{~N}$, $20 \mathrm{~mL})$, sat. $\mathrm{NaHCO}_{3}$ solution $(20 \mathrm{~mL})$, followed by brine $(20$ $\mathrm{mL})$. The organic phase was dried $\left(\mathrm{MgSO}_{4}\right)$, and the solvent was removed in vacuo to obtain the pure product 5 without further purification as a brown, sticky solid (1.056 g, 83\%). $R_{\mathrm{f}}$ $=0.65(\mathrm{DCM}, 5 \% \mathrm{MeOH}) \cdot[\alpha]_{\mathrm{D}}^{24}-4.0$ (c 1.0, DCM). ${ }^{1} \mathrm{H}$ NMR $\left(500 \mathrm{MHz}, \mathrm{CDCl}_{3}\right) \delta 9.10\left(\mathrm{~s}, 1 \mathrm{H}, \mathrm{NHCOCH}_{2} \mathrm{Br}\right), 8.09-7.90$ (m, 6H, triaz-H, $\mathrm{CONHCH}_{2}-$ triaz and $\left.\mathrm{Ar}-\mathrm{H}\right), 7.75(\mathrm{~s}, 1 \mathrm{H}$,
$\mathrm{Ar}-\mathrm{H}), 5.93(\mathrm{~d}, J=9.2 \mathrm{~Hz}, 2 \mathrm{H}, \mathrm{H}-1), 5.60(\mathrm{t}, J=9.7 \mathrm{~Hz}, 2 \mathrm{H}$, $\mathrm{H}-2), 5.54$ (d, $J=2.9 \mathrm{~Hz}, 2 \mathrm{H}, \mathrm{H}-4), 5.32-5.26$ (m, 2H, H-3), 4.67 (ddd, $J=39.3,15.1,5.4 \mathrm{~Hz}, 4 \mathrm{H}, \mathrm{CH}_{2}-$ triaz), $4.31(\mathrm{t}, J=$ $6.4 \mathrm{~Hz}, 2 \mathrm{H}, \mathrm{H}-5$ ), 4.22-4.11 (m, 4H, H-6 and H-6'), 3.98 (s, $2 \mathrm{H}, \mathrm{CH}_{2}-\mathrm{Br}$ ), 2.21 (s, 6H, OAc), 2.00 (app d, $J=2.7 \mathrm{~Hz}, 12 \mathrm{H}$, $\mathrm{OAc} \times 2), 1.82(\mathrm{~s}, 6 \mathrm{H}, \mathrm{OAc}) .{ }^{13} \mathrm{C} \mathrm{NMR}\left(125 \mathrm{MHz}, \mathrm{CDCl}_{3}\right) \delta$ 170.4 (CO of OAc), 170.1 (CO of OAc), 169.8 (CO of OAc), 169.4 (CO of OAc), $166.5\left(\mathrm{CONHCH}_{2}-\right.$ triaz $), 165.0$ $\left(\mathrm{COCH}_{2} \mathrm{Br}\right), 145.6$ (C-triaz), $138.3(\mathrm{Ar}-\mathrm{C}), 135.0(\mathrm{Ar}-\mathrm{C})$, 121.6 ( $\mathrm{CH}$-triaz), $121.4(\mathrm{Ar}-\mathrm{CH}), 121.2(\mathrm{Ar}-\mathrm{CH}), 86.2(\mathrm{C}-1)$, 74.0 (C-5), 70.8 (C-3), 68.1 (C-2), 66.8 (C-4), 61.2 (C-6), $35.5\left(\mathrm{CH}_{2}\right.$-triaz), $29.6\left(\mathrm{NHCOCH}_{2} \mathrm{Br}\right), 20.7\left(\mathrm{CH}_{3}\right.$ of $\left.\mathrm{OAc}\right)$, $20.6\left(\mathrm{CH}_{3}\right.$ of $\left.\mathrm{OAc}\right), 20.5\left(\mathrm{CH}_{3}\right.$ of $\left.\mathrm{OAc}\right), 20.3\left(\mathrm{CH}_{3}\right.$ of $\left.\mathrm{OAc}\right)$. IR (film on $\mathrm{NaCl}$ ): 3345, 3087, 2975, 1752, 1651, 1536, 1446, 1371, 1227, 1063, $924732 \mathrm{~cm}^{-1}$. HRMS (ESI+): $\mathrm{m} / z$ calculated for $\mathrm{C}_{44} \mathrm{H}_{52} \mathrm{BrN}_{12} \mathrm{O}_{21}+\mathrm{H}^{+}\left[\mathrm{M}+\mathrm{H}^{+}\right]$: 1122.2539, found 1122.2545 .

$N, N^{\prime}$-Di(2,3,4,6-tetra-O-acetyl- $\beta$-D-galactopyranosyl1,2,3-triazol-4-ylmethyl amide)- $N^{\prime \prime}$-(2-azidoacetamido)-5aminobenzene-1,3-dicarboxamide (6). Compound 5 (231 $\mathrm{mg}, 0.206 \mathrm{mmol}$ ) and $\mathrm{NaN}_{3}(30 \mathrm{mg}, 0.412 \mathrm{mmol})$ were dissolved in anhydrous DMF $(10 \mathrm{~mL})$ and heated to $80{ }^{\circ} \mathrm{C}$. The reaction mixture was allowed to stir for $16 \mathrm{~h}$. The solvent was removed in vacuo, and the resulting residue was redissolved in DCM $(20 \mathrm{~mL})$ and washed with brine $(20$ $\mathrm{mL} \times 3)$. The organic phase was dried over $\mathrm{MgSO}_{4}$ and the solvent was removed in vacuo to obtain the pure product 6 without further purification as a yellow solid $(1.056 \mathrm{~g}, 83 \%) . R_{\mathrm{f}}$ $=0.41$ (DCM:MeOH 9:1). $[\alpha]_{\mathrm{D}}^{22}-5.6$ (c 0.9, DCM). ${ }^{1} \mathrm{H}$ NMR $\left(500 \mathrm{MHz}, \mathrm{CDCl}_{3}\right) \delta 9.10\left(\mathrm{~s}, 1 \mathrm{H}, \mathrm{NHCOCH}_{2} \mathrm{~N}_{3}\right), 8.18(\mathrm{~s}$, $\left.2 \mathrm{H}, \mathrm{NHCH}_{2} \mathrm{CCH}\right), 8.02$ (s, 2H, $\left.\mathrm{Ar}-\mathrm{H}\right), 7.97$ (s, 2H, CHtriaz), $7.82(\mathrm{~s}, 1 \mathrm{H}, \mathrm{Ar}-\mathrm{H}), 5.95(\mathrm{~d}, J=9.2 \mathrm{~Hz}, 2 \mathrm{H}, \mathrm{H}-1), 5.61$ $(\mathrm{t}, J=9.7 \mathrm{~Hz}, 2 \mathrm{H}, \mathrm{H}-2), 5.56(\mathrm{~d}, J=3.1 \mathrm{~Hz}, 2 \mathrm{H}, \mathrm{H}-4), 5.32$ (dd, $J=10.1,3.5 \mathrm{~Hz}, 2 \mathrm{H}, \mathrm{H}-3$ ), 4.67 (ddd, $J=20.4,15.4,5.5$ $\mathrm{Hz}, 4 \mathrm{H}, \mathrm{CH}_{2}$-triaz), $4.34(\mathrm{t}, \mathrm{J}=6.6 \mathrm{~Hz}, 2 \mathrm{H}, \mathrm{H}-5), 4.23-4.13$ $\left(\mathrm{m}, 4 \mathrm{H}, \mathrm{H}-6\right.$ and $\left.\mathrm{H}-6{ }^{\prime}\right), 4.06\left(\mathrm{~s}, 2 \mathrm{H}, \mathrm{CH}_{2}-\mathrm{N}_{3}\right), 2.21(\mathrm{~s}, 6 \mathrm{H}$, OAc), $2.01(\mathrm{~s}, 12 \mathrm{H}, \mathrm{OAc} \times 2), 1.82(\mathrm{~s}, 6 \mathrm{H}, \mathrm{OAc}) .{ }^{13} \mathrm{C} \mathrm{NMR}$ $\left(125 \mathrm{MHz}, \mathrm{CDCl}_{3}\right.$ ) $\delta 170.4$ (CO of OAc), 170.1 (CO of OAc), 169.9 (CO of OAc), 169.3 (CO of OAc), 166.5 $\left(\mathrm{CONHCH}_{2} \mathrm{CCH}\right), 166.3\left(\mathrm{COCH}_{2} \mathrm{~N}_{3}\right), 145.5$ (C-triaz), 138.0 (Ar-C), 134.9 (Ar-C), 121.6 (Ar- $\mathrm{CH}$ and $\mathrm{CH}$-triaz), 121.4 (Ar$\mathrm{CH}$ ), 86.1 (C-1), 73.9 (C-5), 70.8 (C-3), 68.1 (C-2), 66.9 (C4), 61.2 (C-6), $52.5\left(\mathrm{CH}_{2} \mathrm{~N}_{3}\right), 35.4\left(\mathrm{CH}_{2}\right.$-triaz $), 20.7\left(\mathrm{CH}_{3}\right.$ of $\mathrm{OAc}), 20.6\left(\mathrm{CH}_{3}\right.$ of $\left.\mathrm{OAc}\right), 20.5\left(\mathrm{CH}_{3}\right.$ of $\left.\mathrm{OAc}\right), 20.2\left(\mathrm{CH}_{3}\right.$ of OAc). IR (film on $\mathrm{NaCl}$ ): 3342, 2942, 2110, 1747, 1655, 1528, 1427, 1368, 1211, 1046, 923, $733 \mathrm{~cm}^{-1}$. HRMS (ESI+): $\mathrm{m} / z$ calculated for $\mathrm{C}_{44} \mathrm{H}_{52} \mathrm{~N}_{12} \mathrm{O}_{21}+\mathrm{Na}^{+}\left[\mathrm{M}+\mathrm{Na}^{+}\right]:$1107.3268, found 1107.3303 .

Triethylene Glycol Dipropargyl Ether (7). (Adapted from Feng et $\left.\mathrm{al}^{45}\right)$ Triethylene glycol $(1 \mathrm{~mL}, 7.33 \mathrm{mmol})$ was dissolved in dry THF under $\mathrm{N}_{2}$. $\mathrm{NaH}$ (60\% dispersion in oil, $1.172 \mathrm{~g}, 29.3 \mathrm{mmol}$ ) was added, and the reaction mixture was allowed to stir for $1 \mathrm{~h}$. Propargyl bromide ( $4 \mathrm{~mL}, 44 \mathrm{mmol}$ ) was added, and the reaction mixture was allowed to stir for at rt for $48 \mathrm{~h}$. The solvent was removed in vacuo, and the resulting residue was dissolved in DCM $(20 \mathrm{~mL})$ and washed with water $(10 \mathrm{~mL} \times 2)$, dried $\left(\mathrm{MgSO}_{4}\right)$, filtered, and concentrated in vacuo. The crude product was purified by silica gel column chromatography (EtOAc:Pet Ether 2:1) to give the pure product as a yellow oil $(1.526 \mathrm{~g}, 92 \%) .{ }^{1} \mathrm{H}$ NMR $(500 \mathrm{MHz}$, $\left.\mathrm{CDCl}_{3}\right) \delta 4.20\left(\mathrm{~d}, J=2.4 \mathrm{~Hz}, 4 \mathrm{H}, \mathrm{CH}_{2} \mathrm{CCH}\right), 3.72-3.51(\mathrm{~m}$, $\left.12 \mathrm{H}, \mathrm{OCH}_{2} \times 6\right), 2.42\left(\mathrm{t}, \mathrm{J}=2.4 \mathrm{~Hz}, 2 \mathrm{H}, \mathrm{CH}_{2} \mathrm{CCH}\right) .{ }^{1} \mathrm{H}$ 
NMR and ${ }^{13} \mathrm{C}$ NMR spectroscopic data corresponded to that found in the literature. ${ }^{23}$

$N, N^{\prime}$-Di $(2,3,4,6$-tetra-O-acetyl- $\beta$-D-galactopyranosyl1,2,3-triazol-4-ylmethyl amide)-N"-(2-4-((2-(2-(2-(prop-2yn-1-yloxy)ethoxy)ethoxy)ethoxy)methyl)-1H-1,2,3-triazol1-yl)acetamido)-5-aminobenzene-1,3-dicarboxamide (8). 5 $\mathrm{mL}$ of a solution of compound 6 (prepared by dissolving 293 $\mathrm{mg}$ in $22 \mathrm{~mL} \mathrm{CH} \mathrm{CH}_{3} \mathrm{CN}$ and $5 \mathrm{~mL}$ of water, $[1 \mathrm{mM}]$ ) was combined with $5 \mathrm{~mL}$ of a solution of compound 7 (prepared

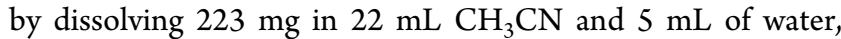
[36 mM]) in a microwave flask. To this solution, $0.5 \mathrm{~mL}$ of a solution of sodium ascorbate (prepared by dissolving $180 \mathrm{mg}$ in $2 \mathrm{~mL}$ of water) was added, followed by $0.5 \mathrm{~mL}$ of a solution of copper sulfate pentahydrate (prepared by dissolving $70 \mathrm{mg}$ in $2 \mathrm{~mL}$ of water). The mixture was allowed to react in the $\mathrm{MW}$ at $100{ }^{\circ} \mathrm{C}$ for $10 \mathrm{~min}$. TLC was used to monitor the reaction; staining the TLC using potassium permanganate solution displayed the product as a bright yellow spot, whereas the starting compound 6 was a white spot and the diclick product was a brown spot on the TLC plate after staining. This procedure was repeated until all the stock solutions were used. The reaction mixture was evaporated and the crude product was purified by silicia gel column chromatography (DCM:MeOH 100:0-90:10) to give the product as a pale yellow solid (160 mg, 45\%). $R_{\mathrm{f}}=0.65(\mathrm{DCM}: \mathrm{MeOH} 9: 1)$. $[\alpha]_{\mathrm{D}}^{23}-1$ (c 1, DCM). ${ }^{1} \mathrm{H}$ NMR $\left(500 \mathrm{MHz}, \mathrm{CDCl}_{3}\right) \delta 9.63(\mathrm{~s}$, $1 \mathrm{H}, \mathrm{NHCH}_{2} \mathrm{~N}_{3}$ ), 8.10 (bs, $2 \mathrm{H}, \mathrm{NHCH}_{2}-$ triaz), 7.91 (s, $2 \mathrm{H}$, $\mathrm{CH}$-triaz), 7.80 (s, 1H, CH-triaz), 7.78 (s, 2H, Ar-H), 7.73 (s, $1 \mathrm{H}, \mathrm{Ar}-\mathrm{H}), 5.85(\mathrm{~d}, J=9.2 \mathrm{~Hz}, 2 \mathrm{H}, \mathrm{H}-1), 5.57(\mathrm{t}, J=9.8 \mathrm{~Hz}$, $2 \mathrm{H}, \mathrm{H}-2), 5.47$ (d, $\mathrm{J}=2.7 \mathrm{~Hz}, 2 \mathrm{H}, \mathrm{H}-4), 5.23-5.19(\mathrm{~m}, 4 \mathrm{H}, \mathrm{H}-$ 3 and $\left.\mathrm{CH}_{2}\right), 4.65-4.56\left(\mathrm{~m}, 6 \mathrm{H}, \mathrm{CH}_{2}\right.$-triaz $), 4.24(\mathrm{t}, J=6.3 \mathrm{~Hz}$, $2 \mathrm{H}, \mathrm{H}-5), 4.13-4.04\left(\mathrm{~m}, 6 \mathrm{H}, \mathrm{H}-6, \mathrm{H}-6^{\prime}\right.$ and $\left.\mathrm{OCH}_{2} \mathrm{CCH}\right)$, $3.61-3.53\left(\mathrm{~m}, 12 \mathrm{H}, 3 \times \mathrm{OCH}_{2} \mathrm{CH}_{2} \mathrm{O}\right), 2.32(\mathrm{~s}, 1 \mathrm{H}, \mathrm{CCH})$, $2.12\left(\mathrm{~s}, 6 \mathrm{H}, \mathrm{CH}_{3}\right.$ of $\left.\mathrm{OAc}\right), 1.94\left(\mathrm{~s}, 12 \mathrm{H}, \mathrm{CH}_{3}\right.$ of $\left.\mathrm{OAc}\right), 1.73$ (s,

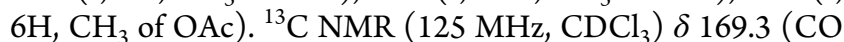
of OAc), 169.1 (CO of OAc), 168.9 (CO of OAc), 168.4 (CO of $\mathrm{OAc}), 165.6\left(\mathrm{CONHCH}_{2}-\right.$ triaz$), 163.3\left(\mathrm{COCH}_{2}-\right.$ triaz $)$, 144.5 (C-triaz), 143.9 (C-triaz), 137.1 (Ar-C), 133.9 (Ar-C), 124.2 ( $\mathrm{CH}$-triaz), 120.7 ( $\mathrm{CH}$-triaz and $\mathrm{Ar}-\mathrm{CH}), 120.4$ (Ar$\mathrm{CH}), 85.1$ (C-1), $78.5(\mathrm{CCH}), 73.9$ (C-5), $72.8(\mathrm{CCH}), 69.7$ (C-3), $69.4\left(\mathrm{CH}_{2} \times 2\right), 69.2\left(\mathrm{CH}_{2}\right), 68.8\left(\mathrm{CH}_{2}\right), 68.0(\mathrm{C}-2)$, 67.0 (C-4), $65.9\left(\mathrm{NHCOCH}_{2} \mathrm{~N}_{3}\right), 60.1 \quad(\mathrm{C}-6), \quad 57.3$ $\left(\mathrm{OCH}_{2} \mathrm{CCH}\right), 52.4\left(\mathrm{CH}_{2}\right), 34.5\left(\mathrm{CH}_{2}\right.$-triaz $), 19.6\left(\mathrm{CH}_{3}\right.$ of $\mathrm{OAc} \times 2), 19.5\left(\mathrm{CH}_{3}\right.$ of $\left.\mathrm{OAc}\right), 19.2\left(\mathrm{CH}_{3}\right.$ of OAc). IR (film on $\mathrm{NaCl}): 3290,3145,2917,2115,1752,1657,1535,1447$, 1370, 1225, 1093, 1054, $924 \mathrm{~cm}^{-1}$. HRMS (ESI+): $\mathrm{m} / z$ calculated for $\mathrm{C}_{56} \mathrm{H}_{70} \mathrm{~N}_{12} \mathrm{O}_{25}+\mathrm{Na}^{+}\left[\mathrm{M}+\mathrm{Na}^{+}\right]$: 1333.4473 , found 1333.4456 .

Synthesis of $N, N^{\prime}-d i(\beta-D-g a l a c t o p y r a n o s y l-1,2,3-t r i a z o l-4-$ ylmethylamide)- $N^{\prime \prime}$-(2-4-((2-(2-(2-(prop-2-yn-1-yloxy)ethoxy)ethoxy)ethoxy)methyl)-1H-1,2,3-triazol-1-yl) acetamido)-5-aminobenzene-1,3-dicarboxamide (9). Compound $8(150 \mathrm{mg}, 0.114 \mathrm{mmol})$ was dissolved in methanol $/ \mathrm{H}_{2} \mathrm{O}(4$ $\mathrm{mL}, 2 \mathrm{~mL}) . \mathrm{NEt}_{3}(0.1 \mathrm{~mL})$ was added, and the reaction mixture was allowed to stir at $45{ }^{\circ} \mathrm{C}$ for $6 \mathrm{~h}$. The solution was cooled, Amberlite $\mathrm{H}^{+}$was added, and the mixture was allowed to stir for $30 \mathrm{~min}$. The solution was filtered, and the solvent was removed in vacuo. Excess $\mathrm{NEt}_{3}$ was removed using the Schlenk line. The product was freeze-dried overnight to yield the pure product 9 as a white solid $(100 \mathrm{mg}, 90 \%) .[\alpha]_{\mathrm{D}}^{23}+7$ (c 1, MeOH: $\mathrm{H}_{2} \mathrm{O} 1: 1$ ). ${ }^{1} \mathrm{H}$ NMR (500 MHz, D2O) $\delta 8.19$ (s, $2 \mathrm{H}, \mathrm{CH}$-triaz), 8.02 (s, 1H, CH-triaz), 7.86 (s, 2H, $\mathrm{Ar}-\mathrm{H})$,
7.78 (s, 1H, Ar-H), 5.58 (d, J = 9.3 Hz, 2H, H-1), 5.34 (s, 2H, $\left.\mathrm{CH}_{2}\right), 4.58\left(\mathrm{~s}, 2 \mathrm{H}, \mathrm{CH}_{2}\right.$-triaz), $4.58\left(\mathrm{~s}, 2 \mathrm{H}, \mathrm{CH}_{2}\right.$-triaz), $4.55(\mathrm{~s}$, $4 \mathrm{H}, \mathrm{CH}_{2}$-triaz), $4.13(\mathrm{t}, J=9.8 \mathrm{~Hz}, 2 \mathrm{H}, \mathrm{H}-2), 4.02(\mathrm{~s}, 2 \mathrm{H}$, $\left.\mathrm{OCH}_{2} \mathrm{CCH}\right), 3.99$ (s, 2H, H-4), 3.89 (m, 2H, H-5), 3.79-3.77 (m, 2H, H-3), 3.68-3.63 (m. 4H, H-6 and H-6'), 3.61 (bs, $\left.2 \mathrm{H}, \mathrm{OCH}_{2}\right), 3.57-3.53\left(\mathrm{~m}, 10 \mathrm{H}, 3 \times \mathrm{CH}_{2}\right), 2.67(\mathrm{~s}, 1 \mathrm{H}$, $\mathrm{CCH}) .{ }^{13} \mathrm{C}$ NMR $\left(125 \mathrm{MHz}, \mathrm{CDCl}_{3}\right) \delta 168.4\left(\mathrm{CONHCH}_{2}-\right.$ triaz), 166.1 ( $\mathrm{COCH}_{2}$-triaz), 144.9 ( $\mathrm{C}$-triaz), 144.2 ( $\mathrm{C}$-triaz), 137.6 (Ar-C), $134.6(\mathrm{Ar}-\mathrm{C}), 126.6$ ( $\mathrm{CH}$-triaz), $123.1(\mathrm{CH}-$ triaz), $123.4(\mathrm{Ar}-\mathrm{CH} \times 2), 88.1(\mathrm{C}-1), 78.3(\mathrm{C}-5), 73.1(\mathrm{C}-3)$, $69.8(\mathrm{C}-2), 69.5\left(\mathrm{CH}_{2}\right), 69.3\left(\mathrm{CH}_{2}\right), 68.6(\mathrm{C}-4), 68.6,68.5(2$ $\left.\times \mathrm{CH}_{2}\right), 63.1 \quad\left(\mathrm{NHCOCH}_{2} \mathrm{~N}_{3}\right), 60.1 \quad(\mathrm{C}-6), 57.8$ $\left(\mathrm{OCH}_{2} \mathrm{CCH}\right), 52.5\left(\mathrm{CH}_{2}\right), 34.1\left(\mathrm{CH}_{2}\right.$-triaz $)$. IR (ATR): 3269, 2927, 2491, 1704, 1645, 1598, 1538, 1447, 1347, 1227, 1090, 1052, $890 \mathrm{~cm}^{-1}$. HRMS (ESI+): $\mathrm{m} / z$ calculated for $\mathrm{C}_{40} \mathrm{H}_{54} \mathrm{~N}_{12} \mathrm{O}_{17}+\mathrm{Na}^{+}\left[\mathrm{M}+\mathrm{Na}^{+}\right]$: 997.3628, found 997.3615.

General Procedure for CuAAC Ligation for Glycoclusters. A solution of $\mathrm{CuSO}_{4} \cdot 5 \mathrm{H}_{2} \mathrm{O}$, tris(3hydroxypropyltriazolylmethyl)amine (THPTA) and sodium ascorbate in phosphate-buffered saline (PBS, pH 7.5, $10 \mathrm{mM}$ ) was added to a solution of the azido-containing compound and the alkyne-containing compound ( 1.5 equiv per azide) in DMF at room temperature. The mixture was degassed under argon and stirred at room temperature for $1 \mathrm{~h}$ under argon. UPLC analysis was used to determine the end point of the reaction. Chelex resin was added to the reaction mixture, which was stirred for an additional $30 \mathrm{~min}$ to remove excess $\mathrm{Cu}^{2+}$ ions. The reaction mixture was then purified by semipreparative RPHPLC to afford pure compounds as white fluffy solids after lyophilization.

Compound 11. A solution of $\mathrm{CuSO}_{4} \cdot 5 \mathrm{H}_{2} \mathrm{O}(0.79 \mathrm{mg}, 3.2$ $\mu \mathrm{mol})$, THPTA $(2.8 \mathrm{mg}, 6.4 \mu \mathrm{mol})$, and sodium ascorbate $(3.8$ $\mathrm{mg}, 19.2 \mu \mathrm{mol})$ in PBS buffer $(400 \mu \mathrm{L}, \mathrm{pH} 7.5)$ was added to a solution of compound $10(7.2 \mathrm{mg}, 6.4 \mu \mathrm{mol})$ and $9(2.74 \mathrm{~mL}$ of $10 \mathrm{mg} / \mathrm{mL}$ solution in PBS, $28.2 \mu \mathrm{mol})$ in $500 \mu \mathrm{L}$ of DMF. The mixture was degassed under argon and stirred at room temperature for $1 \mathrm{~h}$. UPLC analysis showed the reaction was not complete. A further 2 equiv of 9 was added $(1.24 \mathrm{~mL}$ of 10 $\mathrm{mg} / \mathrm{mL}$ solution in PBS, $13.0 \mu \mathrm{mol})$. The mixture was degassed under argon and stirred at room temperature for $1 \mathrm{~h}$. UPLC analysis showed complete coupling. Chelex resin was added to the reaction mixture, which was stirred for an additional $30 \mathrm{~min}$ and purified by semipreparative RP-HPLC $\left(5-40 \% \mathrm{CH}_{3} \mathrm{CN}\right.$ in $\left.15 \mathrm{~min}\right)$ to afford the desired compound 11 as a white fluffy solid after lyophilization $(21 \mathrm{mg}, 65 \%) .{ }^{1} \mathrm{H}$ NMR (500 MHz, D 20$) \delta 8.47(\mathrm{~s}, 1 \mathrm{H}), 8.22(\mathrm{~s}, 8 \mathrm{H}), 8.05(\mathrm{~s}$, $4 \mathrm{H}), 7.95-7.85(\mathrm{~m}, 8 \mathrm{H}), 7.87-7.71(\mathrm{~m}, 8 \mathrm{H}), 5.64(\mathrm{~d}, J=9.2$ $\mathrm{Hz}, 8 \mathrm{H}), 5.37$ (s, 8H), 4.59 (s, 26H), $4.50(\mathrm{~s}, 9 \mathrm{H}), 4.44-4.31$ $(\mathrm{m}, 5 \mathrm{H}), 4.31-4.18(\mathrm{~m}, 19 \mathrm{H}), 4.08(\mathrm{~d}, J=3.3 \mathrm{~Hz}, 8 \mathrm{H}), 4.07-$ $4.00(\mathrm{~m}, 2 \mathrm{H}), 3.97(\mathrm{t}, J=6.1 \mathrm{~Hz}, 8 \mathrm{H}), 3.86(\mathrm{dd}, J=9.8,3.3$ $\mathrm{Hz}, 10 \mathrm{H}), 3.75(\mathrm{~d}, J=6.0 \mathrm{~Hz}, 21 \mathrm{H}), 3.67-3.48(\mathrm{~m}, 53 \mathrm{H})$, $2.96(\mathrm{t}, J=7.6 \mathrm{~Hz}, 2 \mathrm{H}), 2.25(\mathrm{~s}, 3 \mathrm{H}), 2.09-1.47(\mathrm{~m}, 29 \mathrm{H})$, 1.43-1.11 (m, 15H). HRMS (ESI+): $\mathrm{m} / z$ calculated for $\mathrm{C}_{207} \mathrm{H}_{297} \mathrm{~N}_{71} \mathrm{O}_{78}+4 \mathrm{H}^{+}[\mathrm{M}+4 \mathrm{H}]^{4+}:$ 1256.28586, found 1256.28652 .

Compound 12. Compound $11(15.8 \mathrm{mg}, 3.15 \mu \mathrm{mol})$ and $N$-succinimidyl pentynoate $(0.9 \mathrm{mg}, 4.6 \mu \mathrm{mol})$ were dissolved in dry DMF $(1 \mathrm{~mL})$. Diisopropylethylamine $(2 \mu \mathrm{L} \times 3, \mathrm{mmol})$ were added until the solution was at $\mathrm{pH}$ 9. The mixture was stirred at room temperature for $1 \mathrm{~h}$ after which UPLC analysis showed complete conversion. $\mathrm{H}_{2} \mathrm{O}(3 \mathrm{~mL})$ was added to the mixture, which was then purified by semipreparative RP-HPLC 
(5-40\% $\mathrm{CH}_{3} \mathrm{CN}$ in $15 \mathrm{~min}$ ) to afford the desired compound 12 as a white fluffy solid after lyophilization (15.5 mg, 97\%).

Compound 14. A solution of $\mathrm{CuSO}_{4} \cdot 5 \mathrm{H}_{2} \mathrm{O}(0.6 \mathrm{mg}, 2.4$ $\mu \mathrm{mol})$, THPTA $(2.1 \mathrm{mg}, 4.8 \mu \mathrm{mol})$, and sodium ascorbate $(2.9$ $\mathrm{mg}, 28.8 \mu \mathrm{mol})$ in PBS buffer $(400 \mu \mathrm{L}, \mathrm{pH} 7.5)$ was added to a solution of the $13(4 \mathrm{mg}, 2.4 \mu \mathrm{mol})$ and $9(21 \mathrm{mg}, 21.6 \mu \mathrm{mol})$ in $500 \mu \mathrm{L}$ of DMF. The mixture was degassed under argon and stirred at room temperature for $1 \mathrm{~h}$. UPLC analysis showed complete coupling. Chelex resin was added to the reaction mixture, which was stirred for an additional $30 \mathrm{~min}$ and purified by semipreparative RP-HPLC $\left(5-40 \% \mathrm{CH}_{3} \mathrm{CN}\right.$ in 15 $\min$ ) to afford the desired compound 4.55 as a white fluffy solid after lyophilization (6.2 mg, 34\%). ${ }^{1} \mathrm{H}$ NMR (500 MHz, DMSO) $\delta=10.71(\mathrm{~s}, 9 \mathrm{H}), 9.02(\mathrm{~m}, 14 \mathrm{H}), 8.31-8.11(\mathrm{~m}$, $17 \mathrm{H}), 8.01(\mathrm{~m}, 17 \mathrm{H}), 7.95-7.65(\mathrm{~m}, 26 \mathrm{H}), 5.37(\mathrm{~d}, J=9.2$, $12 \mathrm{H}, \mathrm{H}-1), 5.26$ (d, $J=8.1,14 \mathrm{H}), 5.13(\mathrm{~d}, J=5.8,16 \mathrm{H}), 4.94$ $(\mathrm{m}, 20 \mathrm{H}), 4.60(\mathrm{t}, J=5.6,13 \mathrm{H}), 4.55(\mathrm{~d}, J=5.5,9 \mathrm{H}), 4.45$ (dd, $J=12.0,7.6,29 \mathrm{H}), 4.16$ (bs, $26 \mathrm{H}), 3.91$ (dd, $J=15.1,9.2$, $18 \mathrm{H}), 3.65(\mathrm{~m}, 11 \mathrm{H}), 3.60(\mathrm{~m}, 12 \mathrm{H}), 3.41(\mathrm{~m}, 55 \mathrm{H}), 2.97(\mathrm{bs}$, $20 \mathrm{H}), 2.58-2.53(\mathrm{~m}, 7 \mathrm{H}), 2.37-2.25(\mathrm{~m}, 6 \mathrm{H}), 2.1-1.5(\mathrm{~m}$, $54 \mathrm{H}), 1.5-1.0(\mathrm{~m}, 65 \mathrm{H}), 0.81-0.73(\mathrm{~m}, 9 \mathrm{H})$. MALDI-TOFMS $[\mathrm{M}+\mathrm{H}]^{+}: m / z$ calculated for $\mathrm{C}_{314} \mathrm{H}_{442} \mathrm{~N}_{110} \mathrm{O}_{122}+\mathrm{H}^{+}$: 7706.184, found 7706.360 .

Compound 16. A solution of $\mathrm{CuSO}_{4} \cdot 5 \mathrm{H}_{2} \mathrm{O}(0.79 \mathrm{mg}, 3.2$ $\mu \mathrm{mol})$, THPTA $(2.8 \mathrm{mg}, 6.4 \mu \mathrm{mol})$, and sodium ascorbate $(3.8$ $\mathrm{mg}, 19.2 \mu \mathrm{mol})$ in PBS buffer $(400 \mu \mathrm{L}, \mathrm{pH} 7.5)$ was added to a solution of the $15(7 \mathrm{mg}, 6.8 \mu \mathrm{mol})$ and $9(3.9 \mathrm{~mL}$ of $10 \mathrm{mg} /$ $\mathrm{mL}$ solution in PBS, $40.7 \mu \mathrm{mol})$ in $500 \mu \mathrm{L}$ of DMF. The mixture was degassed under argon and stirred at room temperature for $1 \mathrm{~h}$. UPLC analysis showed complete coupling. Chelex resin was added to the reaction mixture, which was stirred for an additional $30 \mathrm{~min}$ and purified by semipreparative RP-HPLC (5-40\% $\mathrm{CH}_{3} \mathrm{CN}$ in $\left.15 \mathrm{~min}\right)$ to afford the desired compound 4.57 as a white fluffy solid after lyophilization (25 mg, 78\%). ${ }^{1} \mathrm{H}$ NMR (500 MHz, $\left.\mathrm{D}_{2} \mathrm{O}\right) \delta$ $8.47(\mathrm{~s}, 1 \mathrm{H}), 8.21(\mathrm{~s}, 8 \mathrm{H}), 8.05(\mathrm{~d}, J=2.4 \mathrm{~Hz}, 4 \mathrm{H}), 7.97-7.88$ (m, 10H), 7.85-7.78 (m, 6H), $5.65(\mathrm{~d}, J=9.1 \mathrm{~Hz}, 8 \mathrm{H}), 5.38$ (s, $8 \mathrm{H}), 5.22(\mathrm{~d}, J=8.2 \mathrm{~Hz}, 4 \mathrm{H}), 4.68-4.55(\mathrm{~m}, 24 \mathrm{H}), 4.52$ $(\mathrm{d}, J=5.2 \mathrm{~Hz}, 9 \mathrm{H}), 4.30-4.14(\mathrm{~m}, 17 \mathrm{H}), 4.08(\mathrm{~d}, J=3.3 \mathrm{~Hz}$, $8 \mathrm{H}), 3.97(\mathrm{t}, J=6.1 \mathrm{~Hz}, 8 \mathrm{H}), 3.86(\mathrm{dd}, J=9.8,3.3 \mathrm{~Hz}, 9 \mathrm{H})$, $3.75(\mathrm{~d}, J=6.0 \mathrm{~Hz}, 17 \mathrm{H}), 3.67-3.47(\mathrm{~m}, 51 \mathrm{H}), 3.00(\mathrm{~s}, 2 \mathrm{H})$, $2.94(\mathrm{t}, J=7.6 \mathrm{~Hz}, 2 \mathrm{H}), 1.88-1.52(\mathrm{~m}, 15 \mathrm{H}), 1.48-1.06(\mathrm{~m}$, $14 \mathrm{H})$. HRMS (ESI+): $m / z$ calculated for $\mathrm{C}_{191} \mathrm{H}_{274} \mathrm{~N}_{68} \mathrm{O}_{75}+$ $4 \mathrm{H}^{+}[\mathrm{M}+4 \mathrm{H}]^{4+}$ : 1179.99237 , found 1179.99202 .

Compound 17. Compound $16(23.6 \mathrm{mg}, 5.0 \mu \mathrm{mol})$ and $N$ succinimidyl pentynoate $(1.46 \mathrm{mg}, 7.5 \mu \mathrm{mol})$ were dissolved in dry DMF $(1 \mathrm{~mL})$. Diisopropylethylamine $(2 \mu \mathrm{L} \times 3, \mathrm{mmol})$ were added until the solution was $\mathrm{pH}$ 9. The mixture was stirred at room temperature for $1 \mathrm{~h}$ after which UPLC analysis showed complete conversion. $\mathrm{H}_{2} \mathrm{O}(3 \mathrm{~mL})$ was added to the mixture, which was then purified by semipreparative RP-HPLC (5-40\% $\mathrm{CH}_{3} \mathrm{CN}$ in $15 \mathrm{~min}$ ) to afford the compound 17 as a white fluffy solid after lyophilization $(19.7 \mathrm{mg}, 82 \%)$.

Compound 18. A solution of $\mathrm{CuSO}_{4} \cdot 5 \mathrm{H}_{2} \mathrm{O}(0.08 \mathrm{mg}, 0.32$ $\mu \mathrm{mol})$, THPTA $(0.27 \mathrm{mg}, 0.62 \mu \mathrm{mol})$, and sodium ascorbate $(0.37 \mathrm{mg}, 1.9 \mu \mathrm{mol})$ in PBS buffer $(400 \mu \mathrm{L}, \mathrm{pH} 7.5)$ was added to a solution of the $10(0.7 \mathrm{mg}, 0.62 \mu \mathrm{mol})$ and $\mathbf{1 2}(14 \mathrm{mg}$, $2.74 \mathrm{mmol}$ ) in $500 \mu \mathrm{L}$ of DMF. The mixture was degassed under argon and stirred at room temperature for $1 \mathrm{~h}$. UPLC analysis showed complete coupling. Chelex resin was added to the reaction mixture, which was stirred for an additional 30 min and purified by semipreparative RP-HPLC (5-40\% $\mathrm{CH}_{3} \mathrm{CN}$ in $15 \mathrm{~min}$ ) to afford the desired compound $\mathbf{1 8}$ as a white fluffy solid after lyophilization (12 mg, 89\%). ${ }^{1} \mathrm{H}$ NMR (500 MHz, DMSO) $\delta=10.81(\mathrm{~s}, 31 \mathrm{H}), 9.11(\mathrm{~s}, 42 \mathrm{H}), 8.43(\mathrm{~s}$, $36 \mathrm{H}), 8.22(\mathrm{~s}, 39 \mathrm{H}), 8.08(\mathrm{~m}, 84 \mathrm{H}), 7.82(\mathrm{~m}, 32 \mathrm{H}), 7.39(\mathrm{~s}$, $40 \mathrm{H}), 6.86(\mathrm{~s}, 12 \mathrm{H}), 6.66(\mathrm{~m}, 12 \mathrm{H}), 5.46(\mathrm{~d}, J=9.1,32 \mathrm{H}, \mathrm{H}-$ 1), $5.36(\mathrm{~s}, 34 \mathrm{H}), 5.23(\mathrm{~s}, 34 \mathrm{H}), 5.02(\mathrm{~s}, 36 \mathrm{H}), 4.67(\mathrm{~m}, 70 \mathrm{H})$, $4.53(\mathrm{~m}, 123 \mathrm{H}), 4.27(\mathrm{~s}, 64 \mathrm{H}), 4.11(\mathrm{~s}, 27 \mathrm{H}), 4.00(\mathrm{~d}, J=4.2$, $40 \mathrm{H}), 3.75(\mathrm{~s}, 42 \mathrm{H}), 3.69(\mathrm{t}, J=5.9,40 \mathrm{H}), 3.52(\mathrm{~m}, 266 \mathrm{H})$, $3.00(\mathrm{~s}, 29 \mathrm{H}), 2.80(\mathrm{~s}, 24 \mathrm{H}), 2.64(\mathrm{~s}, 17 \mathrm{H}), 2.40(\mathrm{~m}, 31 \mathrm{H})$, $2.07(\mathrm{~m}, 66 \mathrm{H}), 1.73(\mathrm{~m}, 125 \mathrm{H}), 1.50(\mathrm{~m}, 40 \mathrm{H}), 1.23(\mathrm{~m}$, $156 \mathrm{H}), 0.86(\mathrm{~m}, 17 \mathrm{H})$. MALDI-TOF-MS $[\mathrm{M}+\mathrm{H}]^{+}: \mathrm{m} / z$ calculated for $\mathrm{C}_{895} \mathrm{H}_{1263} \mathrm{~N}_{307} \mathrm{O}_{326}+\mathrm{H}^{+}: 21539.474$, found 21539.616.

Compound 19. A solution of $\mathrm{CuSO}_{4} \cdot 5 \mathrm{H}_{2} \mathrm{O}(0.1 \mathrm{mg}, 0.46$ $\mu \mathrm{mol})$, THPTA $(0.41 \mathrm{mg}, 0.93 \mu \mathrm{mol})$, and sodium ascorbate (0.56 mg, $2.79 \mu \mathrm{mol})$ in PBS buffer $(400 \mu \mathrm{L}, \mathrm{pH} 7.5)$ was added to a solution of the $15(0.76 \mathrm{mg}, 0.93 \mu \mathrm{mol})$ and 17 $(19.7 \mathrm{mg}, 4.11 \mathrm{mmol})$ in $500 \mu \mathrm{L}$ of DMF. The mixture was degassed under argon and stirred at room temperature for $1 \mathrm{~h}$. UPLC analysis showed complete coupling. Chelex resin was added to the reaction mixture, which was stirred for an additional $30 \mathrm{~min}$ and purified by semipreparative RP-HPLC $\left(5-40 \% \mathrm{CH}_{3} \mathrm{CN}\right.$ in $\left.15 \mathrm{~min}\right)$ to afford the desired compound 19 as a white fluffy solid after lyophilization $(16.2 \mathrm{mg}, 87 \%)$. ${ }^{1} \mathrm{H}$ NMR (500 MHz, DMSO) $\delta=10.86$ (s, 24H), 9.17 (s, $32 \mathrm{H}), 8.59(\mathrm{~m}, 26 \mathrm{H}), 8.28(\mathrm{~s}, 34 \mathrm{H}), 8.13(\mathrm{~m}, 80 \mathrm{H}), 7.87(\mathrm{~m}$, $28 \mathrm{H}), 7.34$ (s, 10H), $7.07(\mathrm{~s}, 10 \mathrm{H}), 5.52(\mathrm{~d}, J=9.1,32 \mathrm{H}, \mathrm{H}-$ 1), $5.42(\mathrm{~s}, 32 \mathrm{H}), 5.29(\mathrm{~s}, 30 \mathrm{H}), 5.20(\mathrm{~s}, 22 \mathrm{H}), 5.07(\mathrm{~s}, 30 \mathrm{H})$, $4.73(\mathrm{~m}, 60 \mathrm{H}), 4.57(\mathrm{~m}, 110 \mathrm{H}), 4.25(\mathrm{~m}, 96 \mathrm{H}), 3.80(\mathrm{~s}, 32 \mathrm{H})$, $3.75(\mathrm{t}, J=5.9,30 \mathrm{H}), 3.57(\mathrm{~m}, 260 \mathrm{H}), 3.23(\mathrm{~s}, 16 \mathrm{H}), 3.06(\mathrm{~s}$, $24 \mathrm{H}), 2.92(\mathrm{~m}, 18 \mathrm{H}), 2.71(\mathrm{~m}, 15 \mathrm{H}), 2.43(\mathrm{~m}, 18 \mathrm{H}), 1.79(\mathrm{~m}$, $80 \mathrm{H}), 1.30(\mathrm{~m}, 82 \mathrm{H}), 0.91(\mathrm{~m}, 6 \mathrm{H})$. MALDI-TOF-MS [M + $\mathrm{H}]^{+}: m / z$ calculated for $\mathrm{C}_{815} \mathrm{H}_{1151} \mathrm{~N}_{292} \mathrm{O}_{311}+\mathrm{H}^{+}:$20015.637, found 20015.456.

Biology. Fungal Strain. C. albicans (MEN, serotype B, clinical isolate from a corneal infection) was maintained on sabouraud dextrose agar, and cultures were grow to the stationary phase $\left((1-2) \times 10^{8}\right.$ cells $\left./ \mathrm{mL}\right)$ overnight in YEPD broth $(1 \%(\mathrm{w} / \mathrm{v})$ yeast extract, $2 \%(\mathrm{w} / \mathrm{v})$ bacteriological peptone, $2 \%(\mathrm{w} / \mathrm{v})$ glucose $)$ at $30{ }^{\circ} \mathrm{C}$, and $200 \mathrm{rpm}$. Stationary phase yeast cells were harvested, washed with PBS, and resuspended at a density of $1 \times 10^{8}$ cells $/ \mathrm{mL}$ in PBS.

Buccal Epithelial Cells. Buccal epithelial cells (BECs) were harvested from healthy volunteers by gently scraping the inside of the cheek with a sterile tongue depressor. Cells were washed in PBS and resuspended at a density of $5 \times 10^{5}$ cells $/ \mathrm{mL}$.

Toxicity. The compounds were incubated with $C$. albicans for $24 \mathrm{~h}$; a dilution was performed $(1 / 50)$ and $100 \mu \mathrm{L}$ of the cell suspension was spread on YEPD agar plates. The compounds did not have a fungicidal effect on the yeast (Figure SI-1).

Adherence Assays. Yeast cells were mixed with 50:1 (yeast:BEC) in a final volume of $2 \mathrm{~mL}$ and incubated at 30 ${ }^{\circ} \mathrm{C}$ and $200 \mathrm{rpm}$ for $90 \mathrm{~min}$. The BEC/yeast cell mixture was harvested by passing through a polycarbonate membrane containing $30 \mu \mathrm{m}$ pores which trapped the BECs but allowed unattached yeast cells to pass through. This was washed $2 \times$ with $10 \mathrm{~mL}$ PBS, and cells remaining on the membrane were collected and placed on glass slides which were left to air-dry overnight. The cells were heat-fixed and stained using $0.5 \%$ $(\mathrm{w} / \mathrm{v})$ crystal violet, rinsed using cold water to remove any surplus stain, and left to air-dry for $30 \mathrm{~min}$. The number of $C$. albicans cells adhering to a sample of 200 BECs per treatment was assessed microscopically. In the exclusion assay, the yeast 
cells were incubated for $90 \mathrm{~min}$ in the presence of each compound at the given concentration. After this time, the yeast cells were harvested and washed twice with PBS before being resuspended in $1 \mathrm{~mL}$ PBS before being mixed with BECs (as described). In the competition assay format yeast cells, BECs and compound (at the given concentration) were coincubated for $90 \mathrm{~min}$ prior to harvesting.

SEM Sample Preparation. First, the yeast cells were incubated separately with compounds 1, 14, and 16, along with a control of only yeast in PBS, for $24 \mathrm{~h}$ at $30^{\circ} \mathrm{C}$ and 200 rpm. Sample preparation for SEM was then adapted from Manefield et al. ${ }^{51}$ The cells were fixed to a microscopic cover clip, with $2.5 \%(\mathrm{v} / \mathrm{w})$ glutaraldehyde and kept at $4{ }^{\circ} \mathrm{C}$ for $12 \mathrm{~h}$. The cells were then washed with sterile PBS $(2 \times)$ dehydrated by sequential washing with ethanol series $(70 \%, 95 \%$, and $100 \%)$. The samples were then treated with hexamethyldisilazane (Sigma-Aldrich) and air-dried overnight in a desiccator. The cells were then sputtered with gold $(6-12 \mathrm{~nm})$ prior SEM imaging.

Biofilm. C. albicans cells were washed twice with PBS and enumerated before being resuspended in RPMI to give a cell density of $\left(2 \times 10^{7}\right.$ cells $\left./ \mathrm{mL}\right)$. Compounds were resuspended in PBS to give a concentration of $2 \mathrm{mg} / \mathrm{mL}$. The compounds $(250 \mu \mathrm{L})$ were mixed with RPMI $(250 \mu \mathrm{L})$ in a $1: 1$ ratio to give a concentration of $1 \mathrm{mg} / \mathrm{mL}$. PBS $(250 \mu \mathrm{L})$ was mixed with RPMI $(250 \mu \mathrm{L})$.

C. albicans cells $\left(500 \mu \mathrm{L}, 2 \times 10^{7}\right.$ cells $\left./ \mathrm{mL}\right)$ were incubated with compounds $(1 \mathrm{mg} / \mathrm{mL})$ in a $1: 1$ ratio to give a final cell density to concentration ratio of $5 \times 10^{6}$ cells $/ \mathrm{mL}$. The suspension was incubated for $3 \mathrm{~h}$ at $\mathrm{rt}$ and mixed by vortex every $20 \mathrm{~min}$ to prevent cells from falling out of solution. Cell suspension $(100 \mu \mathrm{L})$ was added to wells of a 96-well flat bottom plate. The plate was incubated at $37{ }^{\circ} \mathrm{C}$ for $24 \mathrm{~h}$. After incubation, the medium was removed from the wells with a pipet, with care taken not to disrupt the biofilm lining the bottom of the plate. Wells were washed twice with $100 \mu \mathrm{L}$ aliquots of PBS to remove unbound yeast cells. Crystal violet $(5 \% \mathrm{v} / \mathrm{v})(100 \mu \mathrm{L})$ was added to each well and incubated at room temperature for $15 \mathrm{~min}$. The crystal violet was removed by pipet as described before. Wells were washed twice with PBS $(100 \mu \mathrm{L})$. The plates were incubated at room temperature for $2 \mathrm{~h}$, with the lids left off and allowed to dry. Acetic acid $(30 \% \mathrm{v} / \mathrm{v})(100 \mu \mathrm{L})$ was added to each well. The plate was incubated for $10 \mathrm{~min}$ and a pipet was used to mix the contents of each well to ensure the biofilm/crystal violet was fully dissolved in the acetic acid. The plate was read at $550 \mathrm{~nm}$ in a 96-well plate reader. The percentage reduction in biofilm was calculated by dividing the absorbance value of the treated cells into that of the control.

Statistics. All experiments were performed on three independent occasions. In each assay the number of yeast cells adhering to 200 randomly chosen BECs was determined. Results are given as mean \pm SEM (Standard Error of the Mean).

\section{ASSOCIATED CONTENT}

\section{(s) Supporting Information}

The Supporting Information is available free of charge at https://pubs.acs.org/doi/10.1021/acs.bioconjchem.1c00115.

Structures and spectroscopic data; images and molecular weights (PDF)

\section{AUTHOR INFORMATION}

\section{Corresponding Authors}

Trinidad Velasco-Torrijos - Department of Chemistry, Maynooth University, Maynooth W23VP22, Co. Kildare, Ireland; The Kathleen Lonsdale Institute for Human Health Research, Maynooth University, Maynooth W23VP22, Co.

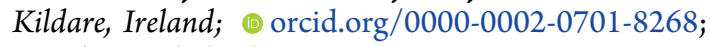
Email: trinidad.velascotorrijos@mu.ie

Olivier Renaudet - DCM, UMR 5250, Université Grenoble Alpes, CNRS, 38000 Grenoble, France; 이이.org/00000003-4963-3848; Email: olivier.renaudet@univ-grenoblealpes.fr

Kevin Kavanagh - Department of Biology and The Kathleen Lonsdale Institute for Human Health Research, Maynooth University, Maynooth W23VP22, Co. Kildare, Ireland; Email: Kevin.Kavanagh@mu.ie

\section{Authors}

Harlei Martin - Department of Chemistry, Maynooth University, Maynooth W23VP22, Co. Kildare, Ireland; (1) orcid.org/0000-0002-6109-9855

David Goyard - DCM, UMR 5250, Université Grenoble Alpes, CNRS, 38000 Grenoble, France; 이이이.org/00000002-6410-0866

Anatte Margalit - Department of Biology, Maynooth University, Maynooth W23VP22, Co. Kildare, Ireland

Kyle Doherty - Department of Chemistry, Maynooth University, Maynooth W23VP22, Co. Kildare, Ireland

Complete contact information is available at:

https://pubs.acs.org/10.1021/acs.bioconjchem.1c00115

\section{Notes}

The authors declare no competing financial interest.

\section{ACKNOWLEDGMENTS}

We would like to thank Irish Research Council (IRC)- Ulysses 2018 for the provision of funding for $\mathrm{H}$. Martin to travel to Prof Renaudet's laboratory. We would like to thank Maynooth University for the provision of the John and Pat Hume Scholarship for H. Martin. We thank the CNRS, Université Grenoble Alpes, ICMG FR 2607, the French ANR project Glyco@Alps (ANR-15-IDEX-02), Labex ARCANE and CBHEUR-GS (ANR-17-EURE-0003). O.R. acknowledge the European Research Council Consolidator Grant “LEGO” (647938) for D.G.

\section{REFERENCES}

(1) Poole, J., Day, C. J., von Itzstein, M., Paton, J. C., and Jennings, M. P. (2018) Glycointeractions in Bacterial Pathogenesis. Nat. Rev. Microbiol. 16, 440-452.

(2) Fuster, M. M., and Esko, J. D. (2005) The Sweet and Sour of Cancer: Glycans as Novel Therapeutic Targets. Nat. Rev. Cancer 5, $526-542$.

(3) Pieters, R. J. (2011) Carbohydrate Mediated Bacterial Adhesion. In Bacterial Adhesion. Advances in Experimental Medicine and Biology (Linke, D., and Goldman, A., Eds.) pp 227-240, Vol. 715, Springer, Dordrecht, The Netherlands. DOI: 10.1007/978-94-007-0940-9 14.

(4) Sattin, S., and Bernardi, A. (2016) Glycoconjugates and Glycomimetics as Microbial Anti-Adhesives. Trends Biotechnol. 34, 483-495.

(5) Cecioni, S., Imberty, A., and Vidal, S. (2015) Glycomimetics versus Multivalent Glycoconjugates for the Design of High Affinity Lectin Ligands. Chem. Rev. 115, 525-561. 
(6) Lehot, V., Brissonnet, Y., Dussouy, C., Brument, S., Cabanettes, A., Gillon, E., Deniaud, D., Varrot, A., Pape, P. L., and Gouin, S. G. (2018) Multivalent Fucosides with Nanomolar Affinity for the Aspergillus fumigatus Lectin FleA Prevent Spore Adhesion to Pneumocytes. Chem. - Eur. J. 24, 19243-19249.

(7) Pertici, F., and Pieters, R. J. (2012) Potent Divalent Inhibitors with Rigid Glucose Click Spacers for Pseudomonas aeruginosa Lectin LecA. Chem. Commun. 48, 4008-4010.

(8) Buffet, K., Nierengarten, I., Galanos, N., Gillon, E., Holler, M., Imberty, A., Matthews, S. E., Vidal, S., Vincent, S. P., and Nierengarten, J. F. (2016) Pillar[5]arene-Based Glycoclusters: Synthesis and Multivalent Binding to Pathogenic Bacterial Lectins. Chem. - Eur. J. 22, 2955-2963.

(9) Hartmann, M., and Lindhorst, T. K. (2011) The Bacterial Lectin FimH, a Target for Drug Discovery - Carbohydrate Inhibitors of Type 1 Fimbriae-Mediated Bacterial Adhesion. Eur. J. Org. Chem. 2011, 3583-3609.

(10) Jiang, X., Abgottspon, D., Kleeb, S., Rabbani, S., Scharenberg, M., Wittwer, M., Haug, M., Schwardt, O., and Ernst, B. (2012) antiadhesion Therapy for Urinary Tract Infections - A Balanced PK/PD Profile Proved to be Key for Success. J. Med. Chem. 55, 4700-4713.

(11) Varrot, A., Basheer, S. M., and Imberty, A. (2013) Fungal Lectins: Structure, Function and Potential Applications. Curr. Opin. Struct. Biol. 23, 678-85.

(12) Sauer, M. M., Jakob, R. P., Luber, T., Canonica, F., Navarra, G., Ernst, B., Unverzagt, C., Maier, T., and Glockshuber, R. (2019) Binding of the Bacterial Adhesin FimH to Its Natural, Multivalent High-Mannose Type Glycan Targets. J. Am. Chem. Soc. 141, 936-944.

(13) Zahorska, E., Kuhaudomlarp, S., Minervini, S., Yousaf, S., Lepsik, M., Kinsinger, T., Hirsch, A. K. H., Imberty, A., and Titz, A. (2020) A Rapid Synthesis of Low-Nanomolar Divalent LecA Inhibitors in Four Linear Steps from D-Galactose Pentaacetate. Chem. Commun. 56, 8822-8825.

(14) Dimick, S. M., Powell, S. C., McMahon, S. A., Moothoo, D. N., Naismith, J. H., and Toone, E. J. (1999) On the Meaning of Affinity: Cluster Glycoside Effects and Concanavalin A. J. Am. Chem. Soc. 121, 10286-10296.

(15) Ernst, B., and Magnani, J. L. (2009) From Carbohydrate Leads to Glycomimetic Drugs. Nat. Rev. Drug Discovery 8, 661-77.

(16) Lee, Y. C., and Lee, R. T. (1995) Carbohydrate-Protein Interactions: Basis of Glycobiology. Acc. Chem. Res. 28, 321-327.

(17) Bernardi, A., Jiménez-Barbero, J., Casnati, A., De Castro, C., Darbre, T., Fieschi, F., Finne, J., Funken, H., Jaeger, K. E., Lahmann, M., et al. (2013) Multivalent Glycoconjugates as Anti-Pathogenic Agents. Chem. Soc. Rev. 42, 4709-4727.

(18) Sansone, F., and Casnati, A. (2013) Multivalent Glycocalixarenes for Recognition of Biological Macromolecules: Glycocalyx Mimics Capable of Multitasking. Chem. Soc. Rev. 42, 4623-4639.

(19) Roy, R., Shiao, T. C., and Rittenhouse-Olson, K. (2013) Glycodendrimers: Versatile Tools for Nanotechnology. Braz. J. Pharm. Sci. 49, 85-108.

(20) Martínez, Á., Ortiz Mellet, C., and García Fernández, J. M. (2013) Cyclodextrin-Based Multivalent Glycodisplays: Covalent and Supramolecular Conjugates to Assess Carbohydrate-Protein Interactions. Chem. Soc. Rev. 42, 4746-4773.

(21) Nierengarten, I., and Nierengarten, J. F. (2014) Fullerene Sugar Balls: A New Class of Biologically Active Fullerene Derivatives. Chem. - Asian J. 9, 1436-1444.

(22) Miura, Y., Hoshino, Y., and Seto, H. (2016) Glycopolymer Nanobiotechnology. Chem. Rev. 116, 1673-1692.

(23) Marradi, M., Chiodo, F., Garcia, I., and Penades, S. (2013) Glyconanoparticles as Multifunctional and Multimodal Carbohydrate Systems. Chem. Soc. Rev. 42, 4728-4745.

(24) Benito-Alifonso, D., Tremel, S., Hou, B., Lockyear, H., Mantell, J., Fermin, D. J., Verkade, P., Berry, M., and Galan, M. C. (2014) Lactose as a "Trojan Horse" for Quantum Dot Cell Transport. Angew. Chem., Int. Ed. 53, 810-814.

(25) Dumy, P., Eggleston, I. M., Cervigni, S., Sila, U., Sun, X., and Mutter, M. (1995) A Convenient Synthesis of Cyclic Peptides as
Regioselectively Addressable Functionalized Templates (RAFT). Tetrahedron Lett. 36, 1255-1258.

(26) Bossu, I., Sulc, M., Křenek, K., Dufour, E., Garcia, J., Berthet, N., Dumy, P., Křen, V., and Renaudet, O. (2011) Dendri-RAFTs: A Second Generation of Cyclopeptide-Based Glycoclusters. Org. Biomol. Chem. 9, 1948-1959.

(27) Galan, M. C., Dumy, P., and Renaudet, O. (2013) Multivalent Glyco(cyclo)peptides. Chem. Soc. Rev. 42, 4599-4612.

(28) Fiore, M., Berthet, N., Marra, A., Gillon, E., Dumy, P., Dondoni, A., Imberty, A., and Renaudet, O. (2013) Tetravalent Glycocyclopeptide with Nanomolar Affinity to Wheat Germ Agglutinin. Org. Biomol. Chem. 11, 7113-7122.

(29) Thomas, B., Pifferi, C., Daskhan, G. C., Fiore, M., Berthet, N., and Renaudet, O. (2015) Divergent and Convergent Synthesis of GalNAc-Conjugated Dendrimers using Dual Orthogonal Ligations. Org. Biomol. Chem. 13, 11529-11538.

(30) Porkolab, V., Pifferi, C., Sutkeviciute, I., Ordanini, S., Taouai, M., Thépaut, M., Vivès, C., Benazza, M., Bernardi, A., Renaudet, O., et al. (2020) Development of C-type Lectin-Oriented Surfaces for High Avidity Glycoconjugates: Towards Mimicking Multivalent Interactions on the Cell Surface. Org. Biomol. Chem. 18, 4763-4772.

(31) Goyard, D., Thomas, B., Gillon, E., Imberty, A., and Renaudet, O. (2019) Heteroglycoclusters With Dual Nanomolar Affinities for the Lectins LecA and LecB From Pseudomonas aeruginosa. Front. Chem. 7, 666-666.

(32) Berthet, N., Thomas, B., Bossu, I., Dufour, E., Gillon, E., Garcia, J., Spinelli, N., Imberty, A., Dumy, P., and Renaudet, O. (2013) High Affinity Glycodendrimers for the Lectin LecB from Pseudomonas aeruginosa. Bioconjugate Chem. 24, 1598-1611.

(33) Pifferi, C., Goyard, D., Gillon, E., Imberty, A., and Renaudet, O. (2017) Synthesis of Mannosylated Glycodendrimers and Evaluation against BC2L-A Lectin from Burkholderia cenocepacia. ChemPlusChem 82, 390-398.

(34) Goyard, D., Baldoneschi, V., Varrot, A., Fiore, M., Imberty, A. Richichi, B., Renaudet, O., and Nativi, C. (2018) Multivalent Glycomimetics with Affinity and Selectivity toward Fucose-Binding Receptors from Emerging Pathogens. Bioconjugate Chem. 29, 83-88.

(35) Martin, H., Kavanagh, K., and Velasco-Torrijos, T. (2021) Targeting Adhesion in Fungal Pathogen Candida albicans. Future Med. Chem. 13, 313-334.

(36) Nobile, C. J., and Johnson, A. D. (2015) Candida albicans Biofilms and Human Disease. Annu. Rev. Microbiol. 69, 71-92.

(37) Spampinato, C., and Leonardi, D. (2013) Candida Infections, Causes, Targets, and Resistance Mechanisms: Traditional and Alternative Antifungal Agents. BioMed Res. Int. 2013, 1.

(38) Al-Hatmi, A. M. S., Mohsin, J., Al-Huraizi, A., and Khamis, F. (2021) COVID-19 Associated Invasive Candidiasis. J. Infect. 82, E45E46.

(39) Song, G., Liang, G., and Liu, W. (2020) Fungal Co-infections Associated with Global COVID-19 Pandemic: A Clinical and Diagnostic Perspective from China. Mycopathologia 185, 599-606.

(40) Chen, N., Zhou, M., Dong, X., Qu, J., Gong, F., Han, Y., Qiu, Y., Wang, J., Liu, Y., Wei, Y., et al. (2020) Epidemiological and Clinical Characteristics of 99 Cases of 2019 Novel Coronavirus Pneumonia in Wuhan, China: A Descriptive Study. Lancet 395, 507513.

(41) Arendrup, M. C., and Patterson, T. F. (2017) MultidrugResistant Candida: Epidemiology, Molecular Mechanisms, and Treatment. J. Infect. Dis. 216, S445-S451.

(42) Martin, H., Govern, M. M., Abbey, L., Gilroy, A., Mullins, S., Howell, S., Kavanagh, K., and Velasco-Torrijos, T. (2018) Inhibition of Adherence of the Yeast Candida albicans to Buccal Epithelial Cells by Synthetic Aromatic Glycoconjugates. Eur. J. Med. Chem. 160, 8293.

(43) Martin, H., Somers, T., Dwyer, M., Robson, R., Mullins, S., Pfeffer, F. M., Bjornsson, R., Krämer, T., Kavanagh, K., and VelascoTorrijo, T. (2020) Scaffold Diversity for Enhanced Activity of Glycosylated Inhibitors of Fungal Adhesion. RSC Med. Chem. 11, 1386-1401. 
(44) Bossu, I., Berthet, N., Dumy, P., and Renaudet, O. (2011) Synthesis of Glycocyclopeptides by Click Chemistry and Inhibition Assays with Lectins. J. Carbohydr. Chem. 30, 458-468.

(45) Feng, Y., Li, J., Jiang, L., Gao, Z., Huang, W., Jiang, F., Luo, N., Han, S., Zeng, R., and Yang, D. (2011) Efficient Syntheses and Complexation Studies of Diacetylene-Containing Macrocyclic Polyethers. Eur. J. Org. Chem. 2011, 562-568.

(46) McCall, A. D., Pathirana, R. U., Prabhakar, A., Cullen, P. J., and Edgerton, M. (2019) Candida albicans Biofilm Development is Governed by Cooperative Attachment and Adhesion Maintenance Proteins. NPJ. Biofilms Microbiomes 5, 21.

(47) Talapko, J., Juzbašié, M., Matijevié, T., Pustijanac, E., Bekié, S., Kotris, I., and Skrlec, I. (2021) Candida albicans-The Virulence Factors and Clinical Manifestations of Infection. J. Fungi 7, 79.

(48) Gulati, M., and Nobile, C. J. (2016) Candida albicans Biofilms: Development, Regulation, and Molecular Mechanisms. Microbes Infect. 18, 310-321.

(49) Tsui, C., Kong, E. F., and Jabra-Rizk, M. A. (2016) Pathogenesis of Candida albicans. Pathog. Dis. 74, ftw018.

(50) Hawser, S. P., and Douglas, L. J. (1994) Biofilm Formation by Candida Species on the Surface of Catheter Materials In Vitro. Infect. Immun. 62, 915-921.

(51) Hazrin-Chong, N. H., and Manefield, M. (2012) An Alternative SEM Drying Method using Hexamethyldisilazane (HMDS) for Microbial Cell Attachment Studies on Sub-Bituminous Coal. J. Microbiol. Methods 90, 96-99. 